\title{
TISSUE ENGINEERING FOR ARTICULAR CARTILAGE REPAIR - THE STATE OF THE ART
}

\author{
Brian Johnstone ${ }^{5,9}$, Mauro Alini ${ }^{1,9}$, Magali Cucchiarini ${ }^{2,9}$, George R. Dodge ${ }^{3,9}$, David Eglin ${ }^{1,9}$, Farshid Guilak ${ }^{4,9}$, \\ Henning Madry ${ }^{2,6,9}$, Alvaro Mata ${ }^{7,9}$, Robert L. Mauck ${ }^{3,9}$, Carlos E. Semino ${ }^{8,9}$ and Martin J. Stoddart ${ }^{1,9 *}$ \\ ${ }^{1}$ AO Research Institute Davos, Davos Platz, Switzerland \\ ${ }^{2}$ Centre of Experimental Orthopaedics, Saarland University Medical Centre, Homburg/Saar, Germany \\ ${ }^{3}$ McKay Orthopaedic Research Laboratory, Department of Orthopaedic Surgery, Perelman School of Medicine, \\ University of Pennsylvania, PA, USA \\ ${ }^{4}$ Departments of Orthopaedic Surgery and Biomedical Engineering, Duke University Medical Centre, Durham, \\ NC, USA \\ ${ }^{5}$ Department of Orthopaedics, Oregon Health and Science University, Portland, OR, USA \\ ${ }^{6}$ Department of Orthopaedic Surgery, Saarland University Medical Centre, Homburg/Saar, Germany \\ ${ }^{7}$ School of Engineering \& Materials Science, Queen Mary, University of London, London, UK \\ ${ }^{8}$ Department of Bioengineering, Institute Quimíc of Sarriá (IQS), School of Engineering, \\ Ramon Llull University (URL), Barcelona, Spain \\ ${ }^{9}$ Collaborative Research Partner Acute Cartilage Injury Program of AO Foundation, Davos, Switzerland
}

(All Authors contributed equally to this work)

\begin{abstract}
Adult articular cartilage exhibits little capacity for intrinsic repair, and thus even minor injuries or lesions may lead to progressive damage and osteoarthritic joint degeneration, resulting in significant pain and disability. While there have been numerous attempts to develop tissue-engineered grafts or patches to repair focal chondral and osteochondral defects, there remain significant challenges in the clinical application of cell-based therapies for cartilage repair. This paper reviews the current state of cartilage tissue engineering with respect to different cell sources and their potential genetic modification, biomaterial scaffolds and growth factors, as well as preclinical testing in various animal models. This is not intended as a systematic review, rather an opinion of where the field is moving in light of current literature. While significant advances have been made in recent years, the complexity of this problem suggests that a multidisciplinary approach - combining a clinical perspective with expertise in cell biology, biomechanics, biomaterials science and high-throughput analysis will likely be necessary to address the challenge of developing functional cartilage replacements. With this approach we are more likely to realise the clinical goal of treating both focal defects and even large-scale osteoarthritic degenerative changes in the joint.
\end{abstract}

Keywords: Cartilage; repair; stem cells; scaffolds; gene therapy; tissue engineering; regenerative medicine; translational and preclinical research.

*Address for correspondence:

Dr Martin J. Stoddart

AO Research Institute Davos

Clavadelerstrasse 8

7270 Davos Platz

Switzerland

Telephone Number: +41 (0) 814142448

FAX Number: +41 814142288

E-mail: martin.stoddart@aofoundation.org

\section{Introduction}

The consistently successful repair of articular cartilage defects is still a major clinical challenge. Although initially considered a tissue with a simple structure (Fig. 1), reproducing the finely balanced structural interactions has proven to be difficult. The field of cartilage tissue engineering has developed over the last twenty years but, despite extensive efforts to develop novel biological solutions, there is still a paucity of clinical options for treatment. Although the field has concentrated on finding therapies for focal lesions, it has now developed sufficiently to begin considering the challenge of finding novel solutions for the extensive joint damage seen in osteoarthritis.

The last two decades have borne witness to a huge expansion in biomaterial technologies, cell sources, and molecular and genetic manipulations that have had or could have positive impact on the development of a truly functional tissue engineered cartilage substitute (Chung and Burdick, 2008). In terms of cell sources, the framework provided by isolated chondrocytes allowed for a multitude of tissue engineered cartilage products to be produced in vitro and in vivo - demonstrating in practice that cartilage tissue engineering is possible (Langer and Vacanti, 1993). With the practical clinical limitations surrounding the use of autologous adult cells, the field rapidly moved towards other progenitor cell sources. Since the early work of Johnstone and Yoo as well as Pittenger and colleagues (Johnstone et al., 1998; Pittenger et al., 1999), the use of bone marrow-derived mesenchymal stem cells (MSCs) has found widespread application (Huang et al., 2010a). The work of Gimble, Guilak, Hedrick and colleagues has illustrated the potential of progenitor cells from adipose and other tissues (Erickson et al., 2002; Zuk et al., 2001). Even more recently, the use of embryonic stem cell (ES)-derived and induced pluripotent stem cell (iPS)-derived progenitors has expanded the cellular palette from which to construct cartilaginous tissues (Hoben et al., 2009; Wei et al., 2012; Diekman et al., 2012). 


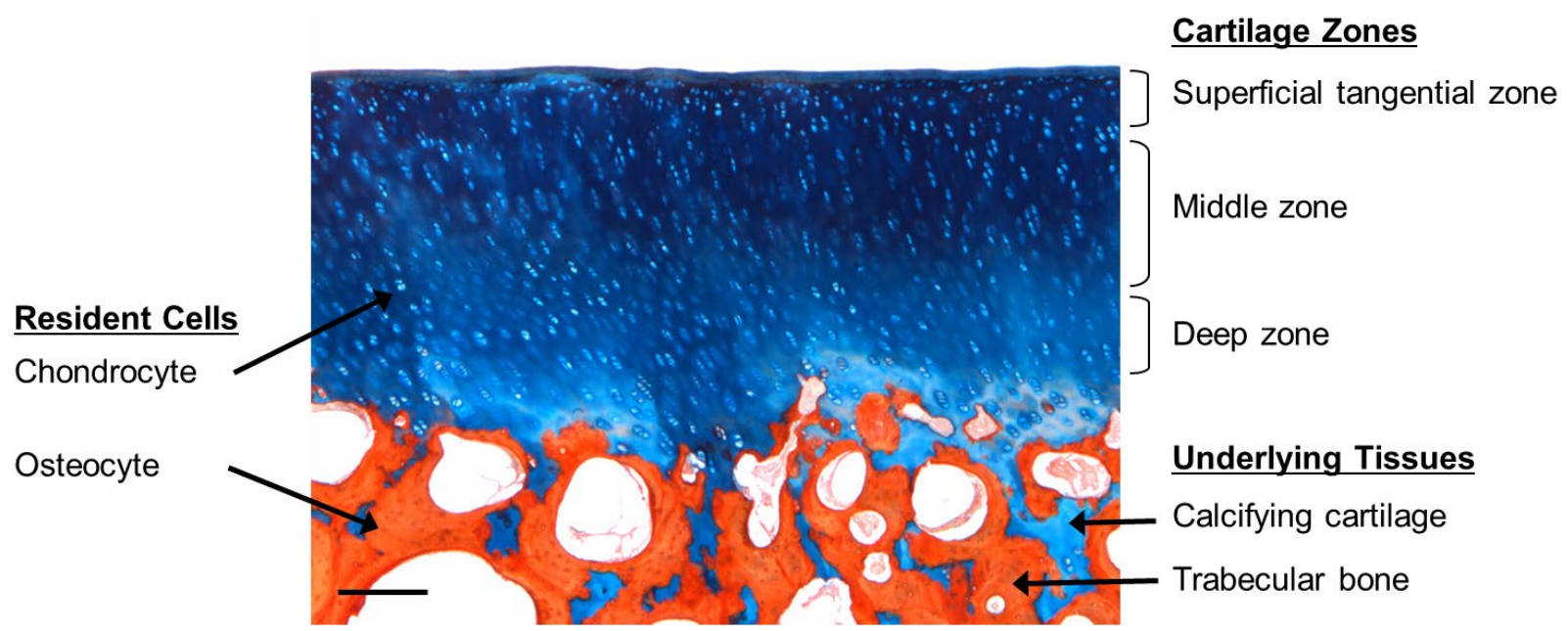

Fig. 1. Section of cartilage detailing the various zones from the upper superficial zone down to the underlying bone. Differences in cell phenotype can be detected between the superficial, middle and deep zones. These differences can still be observed during in vitro culture, demonstrating functional differences between the cells of each zone.

From a biomaterial standpoint, developments (initiated in the early 1990s) have spanned the use of inert and non-biodegradable hydrogel materials (agarose, alginate, and PEG networks) (Buschmann et al., 1992; Elisseeff et al., 2000; Chang et al., 2001) and porous formulations of biodegradable polyesters (Freed et al., 1998; Freed et al., 1993) to the present day application of advanced material chemistries based on both natural and synthetic platforms (Burdick et al., 2005; Lutolf and Hubbell, 2005; Lutolf et al., 2003). Indeed, the concept of a rapidly expanding material framework provides an almost dizzying array of choices for investigators. It is now quite realistic to engineer a material with a host of biologic inputs, while at the same time defining the time course and mechanism by which it ultimately degrades, all the while delivering agents in a controlled fashion. In addition to this cellular and material spectrum, advances in molecular therapeutics continue to provide new and interesting molecules to deliver (as soluble factors or via viral transduction) to cells and/or from the materials themselves. This review aims to detail the role played by the numerous factors involved in the development of tissue engineering therapies for cartilage repair in both focal lesions and osteoarthritis, and highlights the challenges that still need to be overcome in each area. The intention of this review is to illustrate and comment on these challenges; it is not intended to be a comprehensive review of each facet of the field.

\section{Cell sources}

In determining the optimal source of cells for cartilage repair, the two primary criteria that are generally considered are the performance of the cells and their ease of access. Advantages and disadvantages of various cell sources are detailed in Table 1. Regarding performance, primary or low passage articular chondrocytes provide several advantages due to their high level of matrix synthesis and lack of hypertrophy. Indeed, they are the only cell source currently approved for clinical use, albeit without clear clinical advantages over simpler methods, such as microfracture (Knutsen et al., 2007). However, for larger defects, which require a larger number of cells, it is generally accepted that the dedifferentiation and the concomitant advance towards replicative senescence, which occur during monolayer expansion, are significant

Table 1. Advantages and disadvantages of various cell sources.

\begin{tabular}{|l|l|l|}
\hline Cell type & Advantages & Disadvantages \\
\hline $\begin{array}{l}\text { Autologous } \\
\text { chondrocyte }\end{array}$ & $\begin{array}{l}\text { Native phenotype } \\
\text { Minimal risk of immunological problem }\end{array}$ & $\begin{array}{l}\text { Small initial cell number } \\
\text { De-differentiation on expansion }\end{array}$ \\
\hline $\begin{array}{l}\text { Allogeneic } \\
\text { chondrocyte }\end{array}$ & $\begin{array}{l}\text { Larger cell number } \\
\text { Off-the-shelf solution }\end{array}$ & $\begin{array}{l}\text { Limited donor availability } \\
\text { Risk of disease transmission }\end{array}$ \\
\hline $\begin{array}{l}\text { Adult } \\
\text { mesenchymal } \\
\text { stem cells }\end{array}$ & $\begin{array}{l}\text { Potential to produce large numbers } \\
\text { Various harvest sites } \\
\text { Additional paracrine signaling potential }\end{array}$ & $\begin{array}{l}\text { Potential for hypertrophy } \\
\text { Heterogeneous population of cells } \\
\text { Stable and reproducible differentiation still problematic }\end{array}$ \\
\hline $\begin{array}{l}\text { Induced } \\
\text { pluripotent } \\
\text { stem cells (iPS) }\end{array}$ & $\begin{array}{l}\text { Large source of patient specific cells } \\
\text { Multiple cell types can be produced }\end{array}$ & $\begin{array}{l}\text { Stable and reproducible differentiation still problematic } \\
\text { Potential for teratoma }\end{array}$ \\
\hline $\begin{array}{l}\text { Embryonic } \\
\text { stem cells }\end{array}$ & $\begin{array}{l}\text { Off-the-shelf solution } \\
\text { Multiple cell types can be produced }\end{array}$ & $\begin{array}{l}\text { Stable and reproducible differentiation still problematic } \\
\text { Potential for teratoma } \\
\text { Ethical considerations }\end{array}$ \\
\hline
\end{tabular}


hurdles. To eliminate the need for monolayer expansion, there is growing interest in the direct reimplantation of minced cartilage; however, results are still preliminary (McCormick et al., 2008). Furthermore, there is concern that the iatrogenic damage caused by harvesting autologous cartilage for chondrocyte isolation may, by itself, initiate degenerative processes within the joint (Lee et al., 2000), although clinical evidence for this with autologous chondrocyte harvests is limited in the literature (Matricali et al., 2010). With the added requirement for two intraarticular procedures, one to harvest the cartilage and one to re-implant, many groups are attempting to develop other sources of cells for use in articular cartilage repair.

As cartilage is considered to be an immune privileged site, the use of allogeneic chondrocytes is being investigated. Although the results of animal studies have been debated (Moskalewski et al., 2002), it has long been suggested that chondrocytes are privileged by virtue of the barrier properties of their extracellular matrix. Newer data indicate that chondrocytes have immunological properties that limit host immune reaction (Adkisson et al., 2010b). Thus, given their ability to produce abundant matrix, allogenic juvenile chondrocytes have been studied for possible clinical use (Adkisson et al., 2001; Adkisson et al., 2010a) A clinical trial of DeNovo ${ }^{\circledR} \mathrm{ET}$, a de novo tissue derived from juvenile allogeneic chondrocytes, is currently enrolling patients for a Phase III trial. Allogeneic chondrocytes from adult donors are also under clinical investigation (Almqvist et al., 2009; Dhollander et al., 2012b). Cells from non-articular sources, such as ear, nasal and costochondral cells can also proliferate and produce de novo cartilaginous tissue (Tay et al., 2004). The robustness of the tissue produced and its ability to integrate into articular defects remains to be determined. Whether a chondrocyte derived from a different progenitor cell lineage can produce the precise extracellular matrix of articular cartilage is not established. This concern is highly relevant to the study of the many stem and progenitor cell types proposed as alternative cell sources for articular cartilage repair.

While chondrocytes are of great interest, an important advance in the field has been the identification of multiple cell sources that can readily provide large numbers of undifferentiated progenitors with osteogenic and/or chondrogenic potential. Adult bone marrow mesenchymal stem cells (MSCs) (Pittenger et al., 1999) are being extensively studied, as are adipose stem cells (ASCs) (Erickson et al., 2002; Zuk et al., 2001), which may provide a more abundant source of cells for musculoskeletal regeneration (Guilak et al., 2010). The presence of multipotent progenitor cell types in tissues such as muscle (Adachi et al., 2002), periosteum (Nakahara et al., 1991), synovium (De Bari et al., 2001), or infrapatellar fat pad (Wickham et al., 2003) provide additional cell sources that may be readily accessible during joint surgery. Although these cells have been investigated for over 40 years, the methods used for their isolation are still fairly rudimentary. For marrow, adipose and synovial cells, the most common method used is simple adherence to tissue culture plastic. There is no single marker that distinguishes adult stem cells, but the fraction may be selectively enriched using cell surface proteins (CD markers, for a review see
(Harichandan and Buhring, 2011)). All the evidence would suggest that the currently used marker set is able to distinguish mesenchymal cells from haematopoietic cells, but may not be of use to select for a pure MSC population (Whitney et al., 2009). Moreover, it is well appreciated that there exists considerable heterogeneity in the starting MSC population, and so surface markers that identify both MSCs and their potential towards cartilage matrix formation would be especially beneficial to the field. Future progress in the control of differentiation of these cells will be hindered until more selective markers can be identified.

Once isolated, there are various protocols that are currently used to induce chondrogenic differentiation of stem cells. Typically, the protocol involves the application of a chondrogenic stimulus in the form of exogenous transforming growth factor $\beta$ (TGF- $\beta$ ) and dexamethasone, as originally developed for postnatal bone marrow-derived MSCs (Johnstone et al., 1998). However, this chondrogenic differentiation includes an upregulation of genes such as collagen X, alkaline phosphatase (ALP) and MMP13 (Johnstone et al., 1998; Pelttari et al., 2006; Mwale et al., 2006), indicative of a hypertrophic phenotype, suggesting that the process these cells undergo is endochondral. It should be noted that the increased expression of collagen $\mathrm{X}$ is so rapid that doubts have been raised as to its validity as an in vitro hypertrophy marker (Mwale et al., 2006). Regardless of this fact, the molecular profile produced by stem cells differentiated in vitro remains quite distinct from that of articular chondrocytes treated in the same fashion (Huang et al., 2010b) and is seen as undesirable for the repair of a permanent articular surface. It has been proposed that one cell type that might not progress to hypertrophy would be a chondroprogenitor isolated from the cartilage tissue itself (Dowthwaite et al., 2004). Such cells have been isolated by their ability to attach rapidly to fibronectin-coated plastic and exhibit a high proliferative capacity (Khan et al., 2009). Upon in vitro chondrogenic induction, these cells do not express ALP or collagen X and as such may provide a useful source of material for future clinical application (Williams et al., 2010; McCarthy et al., 2012). However, there is still controversy regarding their exact identity and additional work needs to be done to characterise these cells and their function. This source suffers from the same problem as chondrocytes, in that an initial harvest of articular cartilage is required. An improved understanding of the differences between joint tissue-derived stem cells, such as from synovium or articular cartilage, and other adult stem cells such as MSCs would provide new insights into the processes that lead to the stable articular chondrocyte phenotype in vivo.

As noted above, ASCs are gaining increasing interest for cartilage repair due to the large numbers that can be obtained through a relatively simple liposuction procedure. In this regard, the hope is that sufficient numbers can be obtained without the need for a monolayer expansion step. As the monolayer expansion stage needs to be performed individually for each patient, and must be performed under GMP conditions, it not only increases the time before the implantation can be performed but also greatly increases the cost. While unexpanded bone marrow-derived mononuclear cells are being investigated in clinical use, 
their initial yield is lower. Thus, the promise of ASCs is that they offer the largest initial cell yield, and hence the least need for expansion. How best to utilise these cells is still open to discussion. A number of groups have compared ASCs to other sources, such as bone marrow, and demonstrated that they have a lower chondrogenic potential if cultured under the same conditions as MSCs. This can be overcome in part by the addition of further factors, such as BMP-6 (Estes et al., 2010), but additional work needs to be done to improve their efficacy. In addition, the mixed cell population originally isolated may have a larger number of contaminating adherent cells, such as endothelial cells, that also need to be considered.

Chondrogenic differentiation using embryonic stem cells (ESCs) is much less common, though increasingly represented in the literature (Hwang et al., 2008; Hoben et al., 2009; Koay and Athanasiou, 2009). In part, this is due to these cells being highly regulated and for ethical reasons. Not only does special permission need to be obtained to allow work to be carried out with these cells, but also their clinical application for non-life threatening diseases might be limited on an ethical basis. Therefore, their study has mainly been limited to understanding more fundamental biological questions, as opposed to delivering a clinically applicable strategy. One of the main stated advantages of embryonic stem cells is their immunosuppressive properties and their protection from the host immune response, due to a lack of expression of MHC II (Drukker et al., 2002). This has been proposed as a rationale for using these cells in an "off-the-shelf" treatment. What is not clear is what happens to these cells once they differentiate and participate in a repair environment. If MHCII expression is induced during differentiation, these cells may then elicit an immune response. Increasingly, immunosuppressive effects are also being seen in adult MSC populations (De Miguel et al., 2012). Moreover, a better understanding of the population level versus individual cell differentiation response is required. Given the totipotent nature of these cells, even one cell that is not appropriately differentiated could lead to disastrous consequences if it initiates a different or unwanted differentiation response upon implantation. Success of this also depends on the development of additional molecular markers that can be used to identify the specific populations.

Interest in induced pluripotent stem cells (iPSCs) is increasing as they have high differentiation capacity, but also can be produced from the patient's own cells, removing the risk of rejection or disease transmission (Sun et al., 2010). A recent study has shown that iPSCs are capable of robust chondrogenesis using a multi-stage differentiation process involving micromass culture followed by purification of chondrogenic cells using a collagen-2 driven GFP reporter (Diekman et al., 2012). Although the original iPSCs were created using integrating viral vectors, the technology has developed and now episomal vectors with increased safety can be used. It is early days with this cell type and, similar to use of ESCs, issues such as efficiency, reproducibility, standardisation and control of differentiation all need to be addressed before they could be used within a clinical setting. While such cells currently have significant potential for in vitro studies of cartilage injury and osteoarthritis, their clinical application will require a number of years and safety trials to become a reality, so it is likely that an intermediate source would be required. Given the current clinical reality, it is likely that allogeneic chondrocytes will be the next clinical therapy attempted on a large scale, building on current autologous chondrocyte implantation (ACI) techniques. The use of autologous and allogeneic stem cells may be developed sufficiently later, with the use of either iPSCs or ESCs having even greater hurdles to overcome before widespread clinical use for articular cartilage repair would be considered.

\section{Biomaterial platforms for cartilage tissue engineering}

Articular cartilage has a highly organised hierarchical structure composed of three zones: a) a superficial zone, where chondrocytes produce and lay mainly collagen type II in parallel direction to the surface of the tissue; b) a deep zone, located at the cartilage-bone interface where the collagen fibres are aligned perpendicular to the surface; and c) a middle zone characterised by randomly oriented collagen fibres. Of the three, the superficial zone contains the highest proportion of collagen, which results in the high tensile modulus of the tissue and indicates that the main function is to resist the shear stress at the joint surface. The middle zone contains more proteoglycans, which exhibit repulsive negative charges that are neutralised by positive ions, leading to swelling pressures and its highly stable hydrated structure (Poole et al., 2001). These proteoglycans are responsible for the hyaline cartilage's distinctive compression-resistance properties due to the increasing drag forces between the fluid and the matrix that maintain the fluid within the tissue as the cartilage is compressed (Mow et al., 1992). As a consequence, hyaline cartilage of the joint becomes stiffer as the rate of loading increases (Park et al., 2004). This is the reason why hyaline cartilage presents a high compressive modulus. Thus, biomaterials designed with nonlinear, inhomogeneous, and viscoelastic properties that mimic the behaviour of native of hyaline cartilage are most likely to succeed in the functional repair of cartilage defects (Guilak et al., 2001).

Beyond the biomechanical considerations, a new generation of materials are being developed that are influenced by our knowledge of the anatomical and structural complexity of articular cartilage. The increasing capacity to design and synthesise materials with molecular resolution that scales across organisational levels is generating great excitement in the biomaterials community. The combination of technological advances and an increased knowledge in fields such as molecular and cell biology are generating a toolbox with unprecedented precision and versatility to create biomaterial scaffolds with many desired properties. In addition to being biocompatible, an ideal biomaterial scaffold for cartilage regeneration can now be bioactive, biomimetic, biodegradable and bioresponsive, providing signalling with spatio-temporal control and response that is selective to defined stimuli. Materials with such capacities that can also be implanted using minimally invasive procedures are an avenue of intense study. 
Set against this idea of using complex biomaterials for cartilage repair is the concept that since chondrocytes are prolific producers of extracellular matrix, we should be able to create implants from the cells that do not require the addition of biomaterial scaffolds. Two main scaffold-less systems have been described to produce tissue-engineered structures with a cartilage-like characteristics (Kim et al., 2011b; Hu and Athanasiou, 2006; Ofek et al., 2008; Aufderheide and Athanasiou, 2007; Novotny et al., 2006; Kraft et al., 2011). These scaffold-less platforms develop a robust ECM framework of their own and permit longtime maintenance of phenotype, at least in long-term in vitro culture, and can improve biophysical properties by mechanical loading. Scaffold-free constructs using alginate as an intermediate step have also been produced (Masuda et al., 2003) and subjected to mechanical loading (Stoddart et al., 2006). The challenge with such scaffold-free systems is producing them in a cost-effective and timely manner for clinical use, especially with autologous cells. This is also true for scaffold-based systems, but they have the ability to direct growth, have biomechanical properties that are immediately functional in vivo, and can be the designed to deliver relevant bioactive factors in vivo.

\section{Biomaterials currently used in the clinic}

Contemporary clinical procedures for reconstructive cartilage surgery comprise marrow stimulation such as microfracture, mosaicplasty and autologous chondrocyte implantation (ACI). ACI is mainly indicated for large symptomatic defects that are surrounded by nonosteoarthritic cartilage in a stable joint (Gomoll et al., 2012). In fact, for the implanted cells to deposit a new tissue, the damaged site of implantation should provide a permissive environment that may not exist in the case of extensive cartilage loss. Therefore, the classical method of injecting chondrocytes under a periosteal patch (Brittberg et al., 1994) has been abandoned in favour of seeding the cells in biodegradable three-dimensional matrices, such as collagen patches, to physically contain the biologics within the repair site, and more importantly to provide a temporary three-dimensional cartilage-like matrix which supports and promotes healing.

In such applications, the implanted cells are attached to a three-dimensional matrix to contain physically the biologics to the repair site, and to provide a temporary matrix supporting new tissue formation. Among the clinically used scaffolds, type I/III collagen and HA-based materials (e.g. Hyaff-11, Fidia Advanced Biopolymers) are the most commonly described (Grigolo et al., 2001; Haddo et al., 2004). Other biological and synthetic materials and many combinations have been or are being considered; either for their handling properties and relevance as commercial products (e.g. injectable fibrin gels), or their ability to provide a mechanical macro-environment comparable to the one in the joint. However, the clinical data obtained, for example from applying synthetic multiphase polymer scaffolds for osteochondral repair, have been unsatisfactory so far (Dhollander et al., 2012a). In each of these cases, the materials have been specifically designed to be relatively simple in composition. This, combined with the early introduction into the clinic, led to a reduction in the regulatory requirements that would have to be followed by the more complex newer materials now under development.

\section{The next generation of biomaterials}

Classical carriers for articular chondrocytes consist of several matrices, including agarose (Rahfoth et al., 1998; Buschmann et al., 1992), alginate (Hauselmann et al., 1992), hyaluronan (Goa and Benfield, 1994), type I collagen gels and sponges (Ben-Yishay et al., 1995; Frenkel et al., 1997), type II collagen sponges (Nehrer et al., 1998), poly(lactic acid, PLA), and poly(glycolic acid, PGA) (Freed et al., 1994; Vacanti et al., 1991) and fibrin (Itay et al., 1987; Sims et al., 1998). The development of matrix incorporation, and change in equilibrium modulus, can vary depending on the material used (Fig. 2). Hydrogels are attractive for use as cartilage scaffolds because of their unique biocompatibility, capacity to incorporate chemical cues, and innate hydrated structure (Slaughter et al., 2009; Klein et al., 2009). Due to these benefits, ECM-like matrices made from designed molecular building-blocks, such as peptide amphiphiles (Hartgerink et al., 2001), elastin-like polymers (MacEwan and Chilkoti, 2010; Betre et al., 2006), or the commercially available Puramatrix (3DM) (Zhang, 2003), that recreate some of the structural and functional elements of the natural ECM have been developed.

Many of these materials provided good preliminary results in animal models of osteochondral defects, albeit by producing what is generally a fibrocartilaginous repair tissue. Nevertheless, an important concept obtained from these experiments is that defects treated with constructs containing matrices with cells exhibited better performance than matrices alone, supporting the idea that creating therapeutic platforms using both components for articular cartilage repair/regeneration is valid.

More recently, hydrogels based on poly(ethylene glycol) (PEG) macromers, especially diacrylated forms, have received considerable interest due to their ability to be gelled into complex defects (Elisseeff et al., 1999). Ehrbar et al. (2007) developed a PEG gel able selectively to promote cell adhesion and enzymatic degradation, demonstrating the capacity to use such PEG hydrogels as platforms to exhibit specific biomolecular signals. More recently, Nguyen et al. (2011) further increased the complexity of these PEG-based systems, incorporating chondroitin sulphate and matrix metalloproteinasesensitive peptides. A large diversity of PEG hydrogels with potential applications in cartilage regeneration have since been developed (Zhu, 2010; Hwang et al., 2011).

Hydrogels based on hyaluronan (HA) are especially being developed for hyaline cartilage regeneration, due to the possibility of mimicking the natural tissue and the need for obtaining a highly hydrated environment. One of the major limitations, however, is the low mechanical strength of these hydrogels, which require further modification to improve their handling and mechanical properties (Facchini et al., 2006; Grigolo et al., 2001). In order to avoid toxicity complications resulting from modifications, by incorporation of chemical cross-linking agents, a number of groups are exploring innovative alternatives to improve the 


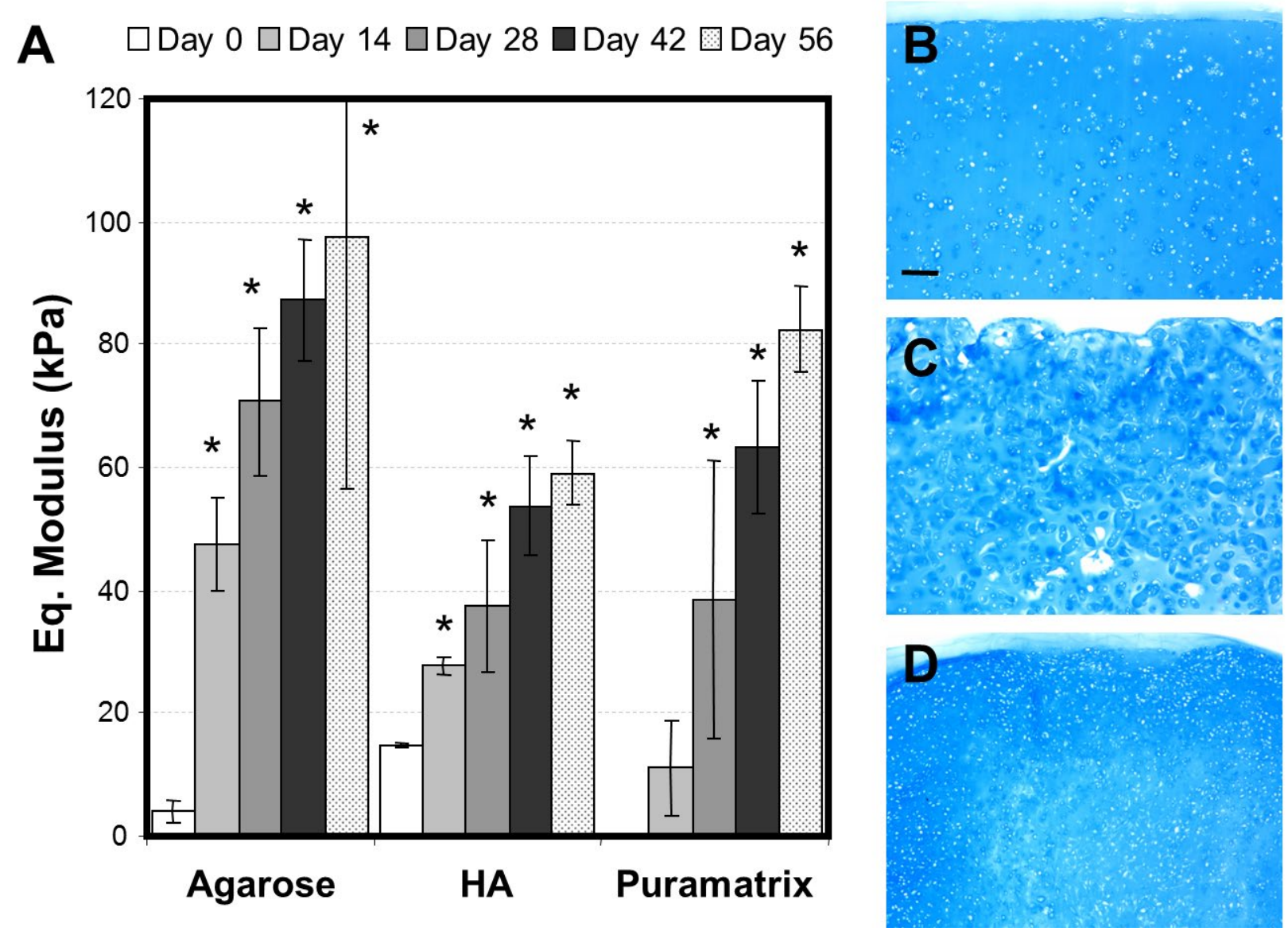

Fig. 2. The development of matrix incorporation, and change in equilibrium modulus (A), can vary depending on the material used. Figure adapted from (Erickson et al., 2009), showing maturation of MSC-seeded hydrogels based on agarose, HA, and Puramatrix. Rich alcian blue staining can be seen in (B) Agarose, (C) HA and (D) Puramatrix.
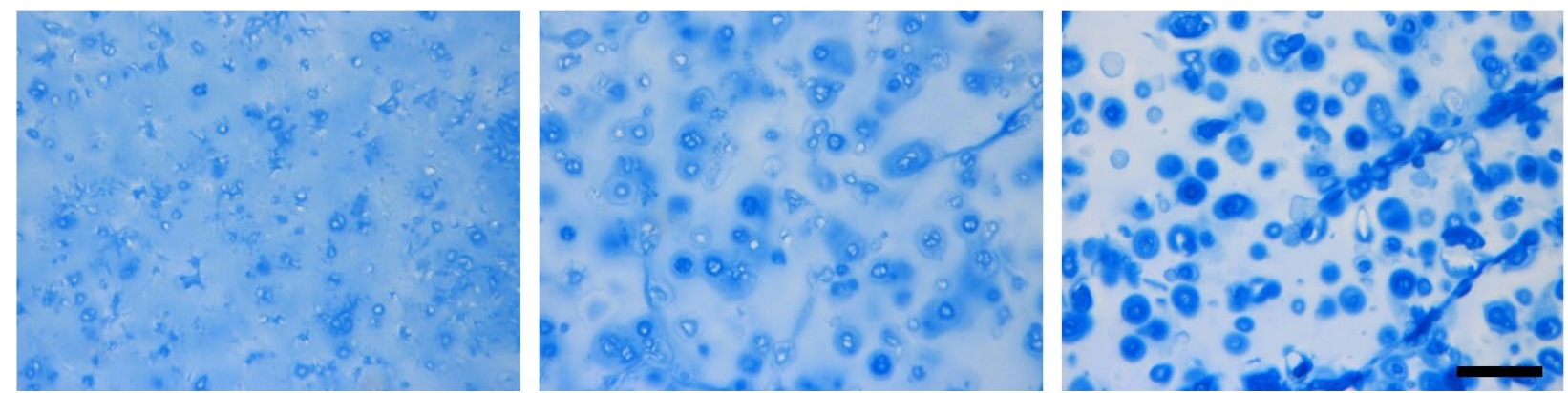

Fig. 3. Matrix distribution in photo-cross-linked MSC-seeded hyaluronic acid hydrogels after $14 \mathrm{~d}$ in chondrogenic culture conditions. Increasing macromer density ( $1 \%$ to $5 \%$ from left to right) increasingly restricts distribution of formed ECM, limiting overall functional properties of constructs with longer term culture. Reproduced with permission from (Erickson et al., 2009).

properties of HA-based hydrogels. One strategy has been the development of composite hydrogels that incorporate structural proteins within the HA material. For example, fibrin/HA hydrogels have been shown to exhibit improved mechanical properties, promote ECM production, and have potential cell delivery capabilities (Rampichova et al., 2010). Another example, reported by Liao et al. (2007), was the development of HA/collagen type I composite hydrogels, which stimulated chondrocyte growth and proteoglycan synthesis as well as overall mechanical properties. Taking advantage of the biological properties of HA molecules and diverse crosslinking mechanisms developed in the last two decades, the influence of the hydrogel mechanical properties, degradation, ability to retain and release growth factors (e.g. TGF- $\beta 1$ ), among others have been extensively studied and demonstrate the usefulness of HA as a backbone for a cartilage biomaterial solution (Erickson et al., 2012; Erickson et al., 2009; Kim et al., 2011a) (Fig. 3). For example, the HA backbone has been modified with methacrylates, allowing for UVmediated polymerisation of the hydrogel (Burdick et al., 2005; Smeds et al., 2001). These materials have been used to encapsulate both chondrocytes and MSCs with promising results (Erickson et al., 2012; Chung et al., 
2006). Another innovative approach has been recently reported by Eglin and co-workers, who developed a modified HA material that incorporates thermosensitive poly( $N$-isopropylacrylamide) (PNIPAM) segments (Mortisen et al., 2010). Above a specific temperature, the modified HA chains undergo conformational changes resulting in their assembly and the formation of stronger hydrogels capable of spontaneous formation and support of cell growth. This approach is highly attractive due to the possibility to develop injectable HA scaffolds that can be implanted through minimally invasive procedures and assemble at the site of injury.

A large number of self-assembling materials based on small molecular building-blocks are being developed (Capito et al., 2009; Wu et al., 2012). For example, Aggeli and colleagues have designed short $\beta$-sheet forming peptides that self-assemble into a variety of nanostructures such as tapes, ribbons and fibrils that form gels with tuneable physical and chemical properties (Aggeli et al., 2003). Pochan and colleagues have developed $\beta$-hairpin peptides that fold intramolecularly to acquire an amphiphilic structure to result in the formation of self-assembled hydrogel networks (Ozbas et al., 2007; Pochan et al., 2003; Schneider et al., 2002). Molecular selfassembling systems are also being developed to incorporate features that enhance the overall hydrogel properties and better mimic fibrocartilage. One of the most promising examples are collagen-mimetic self-assembling peptides developed by Hartgerink and colleagues (Stoop, 2008; O'Leary et al., 2011). These systems are highly attractive due to the possibility of creating a hydrogel that combines both the high water content and the structural integrity found in fibrocartilage.

Another promising family of self-assembling nanofibre scaffolds has been developed by Zhang and co-workers, who have developed alternating positive and negative L-amino acids that self-assemble, through $\beta$-sheet interactions, into nanofibres (Zhang, 2003; Zhao and Zhang, 2007). Liu et al. (2010) have used this material to promote chondrocyte growth and stimulate the production of key hyaline cartilage (aggrecan and collagen type II) markers in vitro. Similar results have been reported by Grodzinsky and colleagues, promoting growth and in vitro chondrogenesis of chondrocytes (Kisiday et al., 2002) and bovine bone marrow stromal cells (Kopesky et al., 2010). More recently, the group of Semino and co-workers reported the spontaneous formation of cartilage tissue from mouse embryonic fibroblasts cultured in self-assembling peptide scaffold RAD16-I (Puramatrix) (Quinatana et al., 2009). Moreover, and using another promising self-assembling platform, Stupp and colleagues have demonstrated a co-assembly system of peptide amphiphiles (PAs) able to self-assemble into nanofibres displaying a high density of binding epitopes for TGF- $\beta-1$ (Shah et $a l ., 2010)$. This study reported the support, survival and chondrogenic differentiation of human mesenchymal stem cells in vitro, as well as regeneration of articular cartilage in a rabbit chondral defect.

In addition to hydrogel formulations and composites, many polymeric and natural biomaterials can be electrospun to obtain biologic and synthetic three-dimensional matrices with nano-scale fibres for chondrocyte culture and phenotype maintenance in vitro. Electrospinning is a relatively simple scaffold fabrication process in which a high electrical potential is applied to a polymer solution. When electrostatic repulsive forces within the solution overcome surface tension, thin strands of polymer are ejected and drawn towards the nearest grounded surface, with whipping and drawing during fibre transit resulting in the collection of stable ultra-fine polymer threads with a nano-scale diameter (Mauck et al., 2009). Towards cartilage tissue engineering, early work by Li and co-workers showed that $3 \mathrm{D}$ nanofibrous poly( $\varepsilon$-caprolactone) (PCL) scaffold composed of electrospun nanofibres supported the chondrocyte phenotype and matrix deposition (Li et al., 2003). Additional work has produced PCL and polylactic acid microfibres scaffolds with 95 and $97 \%$ porosity (Thorvaldsson et al., 2008), and degradable copoly(ether) esterurethane (PDC) or poly(p-dioxanone) (PPDO) using 1,1,1,3,3,3 hexafluoro-2-propanol (HFP) as a solvent (Schneider et al., 2012). This type of degradable polymer is a good material platform candidate for biomaterial-based cartilage repair, in particular when the fibres are sub-micron in diameter ( $\mathrm{Li}$ et al., 2006). In general, chondrocytes seeded in such nanofibrous scaffolds grow well and produce cartilage extracellular markers, such as collagen type II and IX and proteoglycans. Indeed, preliminary studies using PCL scaffolds have been performed in a mini-pig model, showing that the nanofibrous scaffold is well tolerated and can foster tissue regeneration by co-implanted chondrocytes and MSCs (Li et al., 2009). Recent innovations in cartilage tissue engineering with nanofibrous scaffolds have included formation of zonally distinct cartilage layers based on organised nanofibres (McCullen et al., 2012), inclusion of sacrificial fibres to improve composite scaffold colonisation (Baker et al., 2012), and use of native cartilage ECM proteins to form the nanofibres (Shields et al., 2004). This is an extremely active area of research, and will likely provide new and exciting materials to guide cartilage tissue regeneration.

\section{Transition of biomaterials from the laboratory into the clinic}

Articular cartilage plays an important biomechanical role in the body, serving as a load-bearing tissue with distinct mechanical and biological properties at different anatomical sites. In addition, the susceptibility to injury or degenerative disease appears to vary among different sites in the body. Moreover, clinical algorithms for articular cartilage repair are chiefly based, besides clinical symptoms and patient age, on the size and depth of the lesion, its location, and the specific environment of the joint harbouring the articular cartilage defect. The use of new tissue-engineered approaches may depend upon whether defects are osteochondral or purely chondral in nature, potentially requiring specific therapeutic platforms that depend on the type and extent of the injury. Indeed, several biomaterial platforms which overcome general aspects of cartilage disease or trauma are already in the market (with many more in the pipeline). The biological matrices used in clinics may have the ability to provide some of the biological cues that regulate the fate of the implanted 
cells. Collagen and hyaluronan-based biomaterials are the most used in articular cartilage repair, but consideration of the influence of the materials on the cell fate and the type of tissue formed has only been cursorily explored. When considering the use of stem cells, which need precise spatial and temporal signals to differentiate toward a chondrocytic phenotype and avoid hypertrophy, the creation of a material that can provide biological, chemical, and physical cues leading to the optimal cell response is still an important challenge. Recently, a poly(ethylene glycol) diacrylate (PEGDA) hydrogel has been used in a pilot clinical study in combination with microfracture in focal defects of 15 patients.

Perhaps the greatest barriers to be overcome in the translation of new biomaterials into the clinic are the regulatory aspects. Many of the newer proposed biomaterial solutions would be considered as a combination product by the FDA with the scaffold being considered a device and any functionalisation a biologic. Depending on the exact composition, each component may need to be tested for safety individually as well as in combination. For a single composite scaffold with two functionalisation motifs, this could result in four sets of safety data, which would be prohibitively expensive. Each additional component adding increasing levels of testing. This aspect is critical when developing novel biomaterials and should be one of the first steps considered in the process.

\section{Gene transfer}

The concept of applying gene-transfer technologies to treat diseases that affect human joints was initially proposed by Evans et al. in the early 1990s (Bandara et al., 1992; Bandara et al., 1993). The strategy focused on treating patients suffering from rheumatoid arthritis (RA) with ex vivo-modified cells. Here, synovial cells were manipulated using a retroviral vector to carry an interleukin-1 receptor antagonist (IL-1RA) and next injected into the metacarpophalangeal joints of patients (Evans and Robbins, 1995). The protocol successfully led to the production of a biologically active protein, with signs of clinical improvements in the treated cases (Evans et al., 2005b). This approach continues to remain attractive for diseases affecting the synovium (Robbins et al., 2003). However, it might be less adequate to address the clinical problem of focal articular cartilage defects (Evans et al., 2005a; Madry et al., 2011).

\section{The challenge of treating focal articular cartilage defects}

The difficulty in effectively treating such chondral or osteochondral defects with gene therapy is effecting the expression of a candidate gene specifically in the site of a lesion (Cucchiarini and Madry, 2005). This goal is different from the synthesis of a therapeutic product from the synovium that mostly remains diffuse in the synovial fluid. Several groups (Che et al., 2010; Cucchiarini and Madry, 2005; Gelse et al., 2008; Gysin et al., 2002; Ivkovic et al., 2010; Kaul et al., 2006; Madry et al., 2005; Madry et al., 2010a; Neumann et al., 2013; Park et al., 2006;
Turgeman et al., 2001; Vogt et al., 2009) are developing targeted approaches to deliver genetically modified cells or gene vectors directly into cartilage lesions, by means of an arthrotomy or via arthroscopy as demonstrated by Goodrich et al. (2007). This concept is dependent on the feasibility of adequately containing modified cells or vectors in the defect. To address this issue, cell-based strategies in conjunction with biomaterials or the careful local administration of gene vectors have been investigated as a means of providing the therapeutic formulation directly inside the lesion to allow a locally effective and durable transgene expression.

\section{Transplantation of genetically modified cells into cartilage defects}

Implantation of autologous articular chondrocytes (ACI) is a clinically accepted procedure to treat large cartilage defects. In theory, transplantation of genetically modified cells may serve the dual role of providing a cell population capable of proliferating and depositing an extracellular matrix, together with the secretion of the overexpressed protein to stimulate cartilage repair. Based on the large body of data generated from high quality clinical trials (Knutsen et al., 2007; Vanlauwe et al., 2011), articular chondrocytes are a first choice for such approaches; however, recent reports applying unmodified MSCs (Kuroda et al., 2007; Nejadnik et al., 2010) also suggest the theoretical value of genetically modified MSCs (Cucchiarini et al., 2012). Experimental data in small and translational animal models have convincingly shown that such overexpression enhanced the structural features of the repair tissue. Similar to the technique of matrix-assisted ACI (Safran et al., 2008), delivery of genetically modified cells in conjunction with biomaterials is advisable to allow their spatially controlled application to enhance local chondrogenesis. It remains to be seen whether the strategy of cultivating genetically modified cells attached to a biomaterial in a defined biomechanical environment (Grad et al., 2011), reflective of a clinical rehabilitation regimen (Kupcsik et al., 2009), enables further improvements in the performance of such genetically modified grafts (Salzmann et al., 2009).

\section{Direct application of gene vectors to cartilage defects}

With the development of powerful molecular biology tools, some specific gene transfer vectors have emerged for their ability to deliver therapeutic candidate sequences directly in sites of articular cartilage defects (Cucchiarini and Madry, 2005). Instead of using nonviral compounds or classical viral vectors (adeno-/retroviruses), constructs based on the small, non-pathogenic human adenoassociated virus (AAV) have evident clinical advantages, as recombinant AAV (rAAV) vectors effectively transduce most relevant tissues and cells involved in cartilage repair, including the articular cartilage and chondrocytes, the subchondral bone, and MSCs (Cucchiarini and Madry, 2005; Cucchiarini and Madry, 2010). The use of cell- and tissue-specific regulatory elements (promoter/enhancers) (Haleem-Smith et al., 2005; Lefebvre et al., 1996; Xie et al., 1999; Zhou et al., 1998) might be necessary to target a special cell type among all those permissive to rAAV 
transduction, an issue particularly important for direct injection of the vector into the joint. rAAV (a mostly episomal vector that carries no viral sequences) is also more powerful (and is as much or more efficient) than nonviral vectors, and safer than highly immunogenic adenoviruses and integrative retroviral vectors that may lead to tumour gene activation. Although all viral gene vectors have safety considerations, these are being overcome, with the European Medicines Agency recently recommending an rAAV gene therapy for clinical use in the treatment of severe or multiple pancreatitis attacks due to lipoprotein lipase deficiency (Web ref. 1). rAAV has been successfully tested by direct injection in cartilage lesions using an FGF2 gene sequence, showing promising results in terms of healing of rabbit osteochondral defects at four months in vivo (Cucchiarini and Madry, 2005).

\section{Therapeutic candidates}

Equally important, careful selection of therapeutic gene(s) would be essential to treat cartilage defects as there is a need here to enhance the structural quality of the repair tissue, although factors that reduce inflammatory processes (like those applied for RA) may also be valuable. In this regard, reparative and regenerative properties have been attributed to growth and transcription factors (TGF- $\beta$, BMPs, IGF-I, FGF-2, GDF-5, PTHrP; SOX, RUNX2, Cart-1 and Ets families), signalling and regulatory molecules (Wnt, hedgehog families, CD-RAP) and to components of the extracellular matrix or enzymes that produce them (type-II collagen, COMP, tenascin), several of which having been successfully reported to improve the healing of cartilage defects in various experimental models (Cucchiarini and Madry, 2005).

Much work has been already performed in various small (Che et al., 2010; Cucchiarini and Madry, 2005; Gelse et al., 2008; Gysin et al., 2002; Kaul et al., 2006; Madry et al., 2005; Madry et al., 2010a; Park et al., 2006; Turgeman et al., 2001; Vogt et al., 2009) and large animals (Goodrich et al., 2007; Heiligenstein et al., 2011; Hidaka et al., 2003). For instance, it has been shown that tissue-engineered cartilage displays better in vitro properties following genebased modification with IGF-I in vitro (Madry et al., 2002). Ivkovic et al. (2011) used autologous ex vivo-transduced bone marrow via an adenoviral vector carrying TGF- $\beta 1$. Implantation of the resulting marrow clot improved not only the histological and biochemical, but also biomechanical parameters of partial-thickness chondral defects in a sheep model after 6 months in vivo. Hidaka et al. (2003), however, failed to observe biomechanical differences of the repair tissue between groups in a horse model when implanting allogeneic chondrocytes transduced by a BMP7 adenoviral vector. The examples listed here only serve to illustrate the important steps that have been undertaken, and critical review of the literature is recommended for a more comprehensive analysis (Cucchiarini and Madry, 2005; Evans et al., 2005a; Evans, 2011; Evans et al., 2011; Ivkovic et al., 2011; Madry and Cucchiarini, 2011; Madry et al., 2011).

\section{Transition of gene therapies from the laboratory into the clinic}

Taken together, gene transfer might be envisaged as a tool to overexpress a therapeutic factor at the site of the lesion to enhance articular cartilage repair. Thus far, no attempts have been made to replace a defective gene in such an environment. Currently, promising preclinical large animal studies have convincingly shown the potential of this approach, using both cell transplantation and direct approaches. Roadblocks that need to be addressed before this concept can be translated into the clinics include those common to gene-based approaches, such as safety given the non-lethal nature of cartilage diseases, identification of the optimal therapeutic gene(s), long-term transgene expression, ideal biomaterial scaffold and cell type for

Table 2. Advantages and disadvantages of gene transfer vectors.

\begin{tabular}{|c|c|c|c|c|}
\hline Classes & & Advantages & Shortcomings & Integration \\
\hline $\begin{array}{l}\text { Nonviral } \\
\text { vectors }\end{array}$ & & $\begin{array}{l}\text { not infectious } \\
\text { low toxicity } \\
\text { low immunogenicity }\end{array}$ & $\begin{array}{l}\text { low efficiency } \\
\text { short-term expression }\end{array}$ & no \\
\hline \multirow[t]{4}{*}{$\begin{array}{l}\text { Viral } \\
\text { vectors }\end{array}$} & $\begin{array}{l}\text { Adenoviral } \\
\text { vectors }\end{array}$ & highly efficient & $\begin{array}{l}\text { toxicity } \\
\text { immunogenicity } \\
\text { short-term expression } \\
\text { replication competence? }\end{array}$ & no \\
\hline & Retroviral vectors & long-term expression & $\begin{array}{l}\text { efficient, but cell selection generally needed } \\
\text { risk of insertional mutagenesis (activation of tumor genes?) } \\
\text { replication competence }\end{array}$ & yes \\
\hline & HSV vectors & highly efficient & $\begin{array}{l}\text { cytotoxicity } \\
\text { short-term expression }\end{array}$ & no \\
\hline & rAAV vectors & $\begin{array}{l}\text { highly efficient } \\
\text { low toxicity } \\
\text { low immunogenicity } \\
\text { long-term expression }\end{array}$ & production complex & not as a vector \\
\hline
\end{tabular}

HSV: herpes simplex virus; rAAV: recombinant adeno-associated virus 
implantation of these genetically modified cells, together with regulatory gene sequences. The advantages and disadvantages of various viral vectors are detailed in Table 2. Possible side-effects have also to be ruled out. These include, for example, the formation of osteophytes, as observed following intra-articular injection of a BMP-2 adenoviral vector (Gelse et al., 2001). However, when using an ex vivo approach (Gelse et al., 2001) to directly implant modified cells in conjunction with a matrix into the defect, such effects appear unlikely, as the many animal studies that used this approach showed unchanged levels of the therapeutic protein in the synovial fluid. Moreover, it is clear that such genetic modification adds another level of costs to these procedures. That stated, the field of articular chondrocyte implantation already has all the tools necessary to move this concept into a clinical situation, including GMP level facilities for each of the steps required. The optimal cell dose would also have to be defined. In ACI, $1 \times 10^{6}$ cells $/ \mathrm{cm}^{2}$ of defect area are typically implanted (Niemeyer et al., 2013; Safran et al., 2008). For a human gene therapy trial, a similar dose may be selected as a starting point of evaluation.

\section{Beyond focal cartilage defects: can we resurface the whole joint?}

The great majority of approaches for cell-based or tissueengineered repair of articular cartilage defects have focused on the treatment of focal chondral defects (i.e., less than $\sim 4-5 \mathrm{~cm}^{2}$ ) (Farr et al., 2011). Such lesions may be the source of significant pain and disability, and the presence of a cartilage defect may in fact initiate a degenerative condition that affects the entire joint (Lee et al., 2000). Joint injury is one of the primary risk factors for osteoarthritis, and cartilage defects tend to progress in people with symptomatic osteoarthritis (Davies-Tuck et al., 2008). Furthermore, MRI and arthroscopy studies show a high incidence of cartilage lesions are present in asymptomatic joints, particularly in athletes (Flanigan et al., 2010).

However, data on the overall incidence of focal chondral or osteochondral lesions are scarce. Retrospective studies suggest that nearly $60 \%$ of knees undergoing arthroscopy possess some type of chondral lesion, although a small fraction of these are symptomatic (Curl et al., 1997). If other joints such as the ankle, hip and shoulder are considered, the overall incidence of focal cartilage defects is significantly increased. In contrast to such focal lesions, osteoarthritis is a painful and debilitating disease of the entire synovial joint, characterised by progressive degenerative changes in the articular cartilage, subchondral bone, menisci, synovium and most other joint tissues. The overall incidence of osteoarthritis is believed to be many times higher than that of focal cartilage defects, with estimates of over 150 million people worldwide (Web ref. 2 ), although the great majority of joint replacements are currently performed in the USA and Europe.

To date, there have been few approaches that have attempted tissue-engineered repair of very large cartilage defects, or to treat an osteoarthritic joint, and the primary focus of the field has been on the repair of "circumscribed" or "focal" defects. Numerous challenges exist that have hindered attempts at repair of large defects or the resurfacing of an entire osteoarthritic joint. For example, cell-based therapies for large defects may require significantly greater numbers of cells, which may not be readily available, particularly for autologous primary cells. Once implanted in an arthritic joint, cells may be exposed to biomechanical and inflammatory factors that were related to the degeneration state of the joint, and such altered biomechanics or cytokines may influence chondrogenesis or cause degradation of the implant (Majumdar et al., 2001; Wehling et al., 2009).

From a biomechanical standpoint, the larger the defect, the more difficult it will be to restore the native mechanical environment of the joint, which requires matching the mechanical properties and geometry of the implant. While a small defect may provide support around the rim of the defect to protect a graft as it matures and integrates, larger defects will be more likely to be exposed to high stresses immediately and will require more robust mechanical properties to withstand joint loading. Theoretical models of joint contact have shown that increasing defect size leads to increased stress and strain on the rim of the defect (Pena et al., 2007). With increasing size, a greater proportion of the joint surface is involved, requiring more complex geometries to achieve joint congruence (Latt et al., 2011). At an extreme, total resurfacing of the joint would require an implant that matches the geometry of the whole joint while providing functional mechanical properties upon implantation.

Despite these challenges, significant advances have been made in the past few years toward the development of technologies for resurfacing of large cartilage defects or complete joint surfaces. From a bioengineering perspective, an evolving sub-discipline of tissue engineering, termed "functional tissue engineering", has placed focus on defining the biomechanical design parameters necessary for the success of mechanically functional tissues, and the development of scaffolds and tissue constructs that have appropriate anatomical geometry and mechanical properties to promote osteochondral repair (Guilak et al., 2001). In this respect, a number of novel technologies have led to the development of anatomically shaped scaffolds that are designed to restore joint surface geometry and therefore congruence over large surfaces. For example, moulded agarose constructs overlying trabecular bone have been used to create a construct that matches the anatomical geometry of the patella (Hung et al., 2003). Rapid prototyping methods have also been used to fabricate three-dimensional femoral and tibial cartilage constructs to restore congruent articulating surfaces in small joints (Lee et al., 2010; Woodfield et al., 2009). Importantly, new classes of biomaterials and biomaterial structures have been developed that can not only provide predefined geometries, but possess functional biomechanical properties similar to those of native tissues so that they can withstand joint loading immediately upon implantation (Freed et al., 2009). For example, three-dimensionally woven composite materials can be designed to provide many of the complex properties of native cartilage, including anisotropy, inhomogeneity, nonlinearity, and viscoelasticity (Moutos 
A

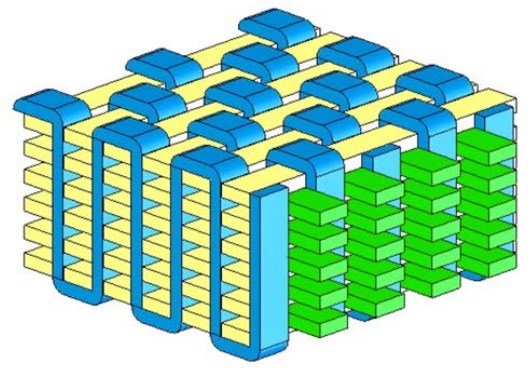

D

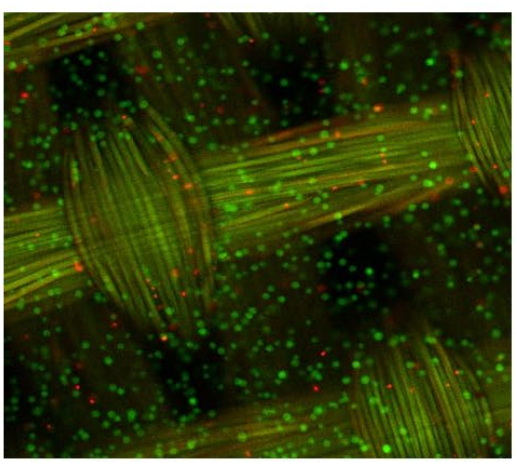

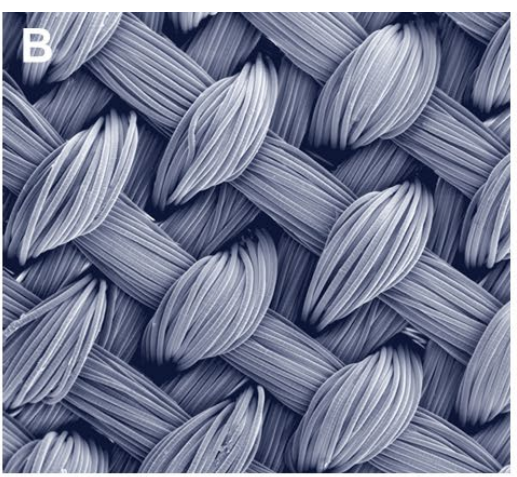

E

3D PCL

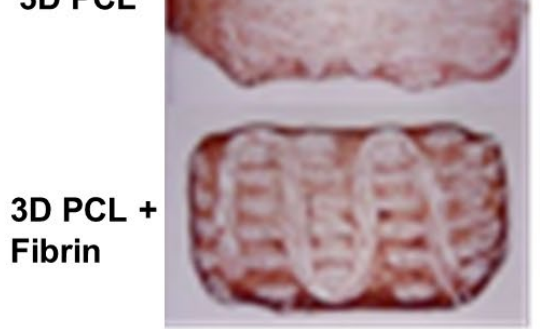

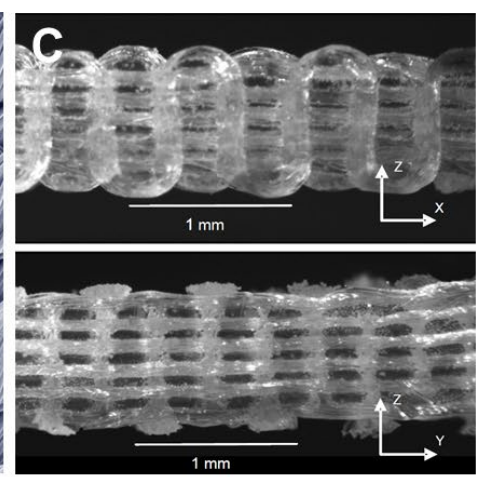

$\mathbf{F}$

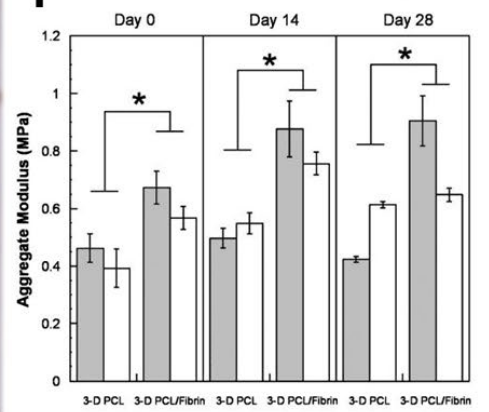

Fig. 4. Three-dimensional woven scaffolds for cartilage tissue engineering. A. Fibre architecture showing the orthogonal structure consisting of multiple layers of $\mathrm{x}$ (green), $\mathrm{y}$ (yellow), and $\mathrm{z}$ (blue) fibers. B. Scanning electron micrograph of the scaffold surface. C. Cross-sectional views of the $x-z$ and $y-z$ planes showing the continuity of the pore structure. D. Live-dead fluorescent labelling of cells seeded within the scaffold. E. Immunohistochemistry for type II collagen production in 3D woven PCL scaffolds seeded with adipose-derived stem cells (ASCs) with or without a fibrin gel. F. Unseeded and ASC-seeded scaffolds exhibit biomimetic cartilage mechanical properties over a $28 \mathrm{~d}$ culture period. Adapted from (Moutos et al., 2007; Moutos and Guilak, 2010).

et al., 2007) (Fig. 4). Similarly, other materials processing techniques, such as electrospinning, can be used to create highly anisotropic materials that can control cellular alignment and matrix deposition (Li et al., 2007).

Thus, while significant progress is being made in the development of cell-based and tissue-engineering strategies for the repair of small osteochondral defects, continuing advances in stem cell biology and scaffold technology may allow the extension of these methods to the treatment of large defects, or perhaps, biologicallybased resurfacing of the entire joint. Nonetheless, a number of challenges still remain in this regard. In addition to the aforementioned biomechanical requirements, the development of large constructs that cover the entire joint surface will require large numbers of cells, emphasising the issues discussed regarding the ease of cell harvesting and expansion. Similarly, the exposure of an engineered tissue to the inflammatory environment of an osteoarthritic joint may inhibit stem cell differentiation, or induce degradation of the newly formed cartilage, further emphasising the need for scaffolds that can provide biomechanical function in such situations (Ousema et al., 2012).

\section{In vitro to in vivo translation - general considerations}

As work with cell sources, biomaterial frameworks and biologic intervention/gene transfer methods to further cartilage tissue engineering matures, the question that arises is how to facilitate, categorise, and benchmark such progress (all of which is occurring simultaneously in many laboratories the world over)? Further, progress towards the realisation of functional engineered cartilage constructs brings up the practical (and moral) question of when is it appropriate and/or expeditious to test these newly developed products in animal models? Secondary to this question is which animal model is best to use?

With the great spectrum of choices that one can make in cartilage tissue engineering, there now exist several critical needs for the field to tackle. First and foremost, a 'common language' must be established to allow for rapid and reliable comparisons across groups. For example, when reporting a mechanical property, it is essential that material properties be reported using the same testing configurations (that "apples" be compared to "apples") and ideally reported with respect to native cartilage tissue tested in the same fashion. Likewise, it would be a great benefit if the community could decide on (and share) a common cell source (including a common culture procedure with defined medium). While this would be difficult to implement due to the lack of consensus on which cell type is most suitable, the inclusion of an additional group which could be used as a reference between studies might be an option in the short term. Here, each new study would then be compared to identical conditions using this 'gold standard', and so relative efficacy of any new cell source or cell-material interaction could be appropriately adjudged. Finally, with the increasing number of choices, we must similarly expand 
our vision in terms of outcome testing. Gone are the days when a study could be done on a sample by sample basis, while still taking advantage of the large parameter space available. We have already seen efforts in the community to develop high throughput screening (HTS) tools, much like those used in the pharmaceutical industry for drug screening, that are specific for cartilage tissue engineering biochemical outcomes (Huang et al., 2008). Along with these HTS assays, the idea of micro-scaling the work will enable a host of conditions to be assayed at once in an economical fashion (Khademhosseini et al., 2006). Still more development is required in this research space. For example, mechanical outcomes must be foremost in any cartilage tissue engineering effort (given the required load bearing characteristics of the tissue), and a focus on a reliable and reproducible mechanical high throughput screening tool for the community should be developed. These advances would allow for a mature field to make rational choices so as to better select new cells, new factors and their combination, and new material formulations for improved cartilage tissue engineering.

While much progress remains to be made in vitro, today there do exist cartilage constructs that approach native tissue values for certain quantitative parameters (including biochemical and mechanical properties) e.g., (Lima et al., 2007; Erickson et al., 2012; Moutos et al., 2007). Where then should such constructs be tested, and what outcome parameters are most important in the in vivo transition of such constructs?

The lapine model of cartilage repair is a good first animal screening system for any new material, provided that skeletally mature rabbits and appropriate negative controls and sample sizes are used (Orth et al., 2012; Laverty et al., 2010; Hunziker, 1999; Buckwalter and Mankin, 1998; Mankin, 1982), but the cartilage is thin, limiting most studies to the study of osteochondral (rather than chondral) healing. When transitioning to a larger animal system, however, the species of choice remains controversial, with various groups advocating mini-pig, dog, sheep, goat or horse as the ideal system (see recent reviews (Chu et al., 2010; Ahern et al., 2009)), with each model having its own benefits and drawbacks. The most appropriate clinical pathology chosen to be studied remains controversial as well; is it better to study osteochondral or chondral lesions? Clinically, the latter are seen more often, but the former may be easier to implement repair solutions for, although they are perhaps more complicated as they involve multiple tissue phases. Furthermore, not addressing a possible underlying subchondral bone pathology that either was induced in response to the cartilage loss or was the initial reason for the cartilage defect would likely diminish the clinical relevance (Gomoll et al., 2010; Lories and Luyten, 2011; Madry et al., 2010b; Madry, 2010). Similarly, there remains the open question as to whether to implant a construct early, allowing maturation to occur in vivo, or whether it is best to implant a fully matured construct. Again, both approaches have clinical relevance and practical issues driving selection. It is also not yet clear what rehabilitation regimens are most appropriate, and whether these can be implemented in the various animal models. In patients, it is not uncommon to institute a low load-bearing rehabilitation regimen for up to three months, but this is difficult to achieve in most animal models. Additionally, the age of the animal model will have a significant impact on outcomes; is it better to test engineered constructs in a young animal, where repair or regeneration is more likely, or in an aged animal or one with concomitant joint pathology so as to better recapitulate the clinical scenario? On one hand, demonstration of efficacy in the absence of challenge may lead to overly optimistic results, while engineering in most difficult scenario may limit progress, when every attempt is a failure. What is clear is that a realistic consensus must be achieved, and that consistent outcome measures should be applied across animal platforms. Moreover, given the distinct environments of in vitro versus in vivo studies, when in vitro constructs demonstrate a certain 'threshold' of function, they should be immediately assayed in a large animal load-bearing environment, so that realistic assessment of their potential can be evaluated. Finally, the relevant funding agencies in Europe, the US, and around the world should be educated on this process, and should support such endeavours to enable and foster progress in this area.

\section{Concluding remarks}

As can be seen from the points raised in this review, the number of potential variables in any cartilage tissue engineering strategy is vast, and those parameters that will be the most critical for functional outcomes have yet to be determined. In addition, it is clear that certain methods and models used are suboptimal for determining the effect that will be seen in a likely patient population. While they are useful for improving academic knowledge, researchers have to be more self-critical if the challenge of translation is to be overcome. Researchers must also become more aware of the regulatory requirements and associated costs that they will face in translating potential therapies into the clinical arena. It has been proposed that rather than waiting until the optimal conditions have been found, intermediate treatments should be investigated and then later improved upon (Evans, 2011). While this approach has its merits, the costs of clinical trials, and the difficulties associated with clinical acceptance and implementation, may make this approach financially nonviable. These hurdles also explain why many published clinical studies are not performed in the optimal manner. The lack of well performed, prospective clinical studies comparing and validating cartilage repair techniques makes drawing conclusions on efficacy problematic. Until a scientifically rigorous and cost effective way of testing novel therapies within a clinical setting is found, translational progress will be painfully slow.

\section{Acknowledgments}

This work was supported by the Collaborative Research Centre, AO Foundation, Davos, Switzerland. We wish to confirm that there are no known conflicts of interest 
associated with this publication and there has been no significant financial support for this work that could have influenced its outcome.

\section{References}

Adachi N, Sato K, Usas A, Fu FH, Ochi M, Han CW, Niyibizi C, Huard J (2002) Muscle derived, cell based ex vivo gene therapy for treatment of full thickness articular cartilage defects. J Rheumatol 29: 1920-1930.

Adkisson HD, Gillis MP, Davis EC, Maloney W, Hruska KA (2001) In vitro generation of scaffold independent neocartilage. Clin Orthop 391: 280-294.

Adkisson HD, Martin JA, Amendola RL, Milliman C, Mauch KA, Katwal AB, Seyedin M, Amendola A, Streeter PR, Buckwalter JA (2010a) The potential of human allogeneic juvenile chondrocytes for restoration of articular cartilage. Am J Sports Med 38: 1324-1333.

Adkisson HD, Milliman C, Zhang X, Mauch K, Maziarz RT, Streeter PR (2010b) Immune evasion by neocartilagederived chondrocytes: Implications for biologic repair of joint articular cartilage. Stem Cell Res 4: 57-68.

Aggeli A, Bell M, Carrick LM, Fishwick CWG, Harding R, Mawer PJ, Radford SE, Strong AE, Boden N (2003) $\mathrm{pH}$ as a trigger of peptide beta-sheet self-assembly and reversible switching between nematic and isotropic phases. J Am Chem Soc 125: 9619-9628.

Ahern BJ, Parvizi J, Boston R, Schaer TP (2009) Preclinical animal models in single site cartilage defect testing: a systematic review. Osteoarthritis Cartilage 17: 705-713.

Almqvist KF, Dhollander AA, Verdonk PC, Forsyth R, Verdonk R, Verbruggen G (2009) Treatment of cartilage defects in the knee using alginate beads containing human mature allogenic chondrocytes. Am J Sports Med 37: 1920 1929.

Aufderheide AC, Athanasiou KA (2007) Assessment of a bovine co-culture, scaffold-free method for growing meniscus-shaped constructs. Tissue Eng 13: 2195-2205.

Baker BM, Shah RP, Silverstein AM, Esterhai JL, Burdick JA, Mauck RL (2012) Sacrificial nanofibrous composites provide instruction without impediment and enable functional tissue formation. Proc Natl Acad Sci USA 109: 14176-14181.

Bandara G, Robbins PD, Georgescu HI, Mueller GM, Glorioso JC, Evans CH (1992) Gene transfer to synoviocytes: prospects for gene treatment of arthritis. DNA Cell Biol 11: 227-231.

Bandara G, Mueller GM, Galea-Lauri J, Tindal MH, Georgescu HI, Suchanek MK, Hung GL, Glorioso JC, Robbins PD, Evans CH (1993) Intraarticular expression of biologically active interleukin 1 receptor antagonist protein by ex vivo gene transfer. Proc Natl Acad Sci USA 90: 10764-10768.

Ben-Yishay A, Grande DA, Schwartz RE, Menche D, Pitman MD (1995) Repair of articular cartilage defects with collagen-chondrocyte allografts. Tissue Eng 1: 119-133.

Betre H, Ong SR, Guilak F, Chilkoti A, Fermor B, Setton LA (2006) Chondrocytic differentiation of human adipose-derived adult stem cells in elastin-like polypeptide. Biomaterials 27: 91-99.
Brittberg M, Lindahl A, Nilsson A, Ohlsson C, Isaksson O, Peterson L (1994) Treatment of deep cartilage defects in the knee with autologous chondrocyte transplantation. N Engl J Med 331: 889-895.

Buckwalter JA, Mankin HJ (1998) Articular cartilage repair and transplantation. Arthritis Rheum 41: 1331-1342.

Burdick JA, Chung C, Jia X, Randolph MA, Langer $\mathrm{R}$ (2005) Controlled degradation and mechanical behavior of photopolymerized hyaluronic acid networks. Biomacromolecules 6: 386-391.

Buschmann MD, Gluzband YA, Grodzinsky AJ, Kimura JH, Hunziker EB (1992) Chondrocytes in agarose culture synthesize a mechanically functional extracellular matrix. J Orthop Res 10: 745-758.

Capito RM, Mata A, Stupp SI (2009) Self-assembling peptide-based nanostructures for regenerative medicine. In: Vogel V (Ed) Nanotechnology, 1st ed. Wiley-VCH, Washington, pp 385-412.

Chang SCN, Rowley JA, Tobias G, Genes NG, Roy AK, Mooney DJ, Vacanti CA, Bonassar LJ (2001) Injection molding of chondrocyte/alginate constructs in the shape of facial implants. J Biomed Mater Res 55: 503-511.

Che JH, Zhang ZR, Li GZ, Tan WH, Bai XD, Qu FJ (2010) Application of tissue-engineered cartilage with BMP-7 gene to repair knee joint cartilage injury in rabbits. Knee Surg Sports Traumatol Arthrosc 18: 496-503.

Chu CR, Szczodry M, Bruno S (2010) Animal models for cartilage regeneration and repair. Tissue Eng Part B Rev 16: 105-115.

Chung C, Burdick JA (2008) Engineering cartilage tissue. Adv Drug Deliv Rev 60: 243-262.

Chung C, Mesa J, Randolph MA, Yaremchuk M, Burdick JA (2006) Influence of gel properties on neocartilage formation by auricular chondrocytes photoencapsulated in hyaluronic acid networks. J Biomed Mater Res A 77: 518-525.

Cucchiarini M, Madry H (2005) Gene therapy for cartilage defects. J Gene Med 7: 1495-1509.

Cucchiarini M, Madry H (2010) Genetic modification of mesenchymal stem cells for cartilage repair. Biomed Mater Eng 20: 135-143

Cucchiarini MC, Venkatesan JK, Ekici M, Schmitt G, Madry H (2012) Genetic modification of human mesenchymal stem cells overexpressing therapeutic genes: from basic science to clinical applications for articular cartilage repair. Biomed Mate Eng 22: 197-208.

Curl WW, Krome J, Gordon ES, Rushing J, Smith BP, Poehling GG (1997) Cartilage injuries: a review of 31,516 knee arthroscopies. Arthroscopy 13: 456-460.

Davies-Tuck ML, Wluka AE, Wang Y, Teichtahl AJ, Jones G, Ding C, Cicuttini FM (2008) The natural history of cartilage defects in people with knee osteoarthritis. Osteoarthritis Cartilage 16: 337-342.

De Bari C, Dell'Accio F, Tylzanowski P, Luyten FP (2001) Multipotent mesenchymal stem cells from adult human synovial membrane. Arthritis Rheum 44: 19281942.

De Miguel MP, Fuentes-Julian S, Blazquez-Martinez A, Pascual CY, Aller MA, Arias J, Arnalich-Montiel F (2012) Immunosuppressive properties of mesenchymal stem cells: advances and applications. Curr Mol Med 12: 574-591. 
Dhollander AA, Liekens K, Almqvist KF, Verdonk R, Lambrecht S, Elewaut D, Verbruggen G, Verdonk PC (2012a) A pilot study of the use of an osteochondral scaffold plug for cartilage repair in the knee and how to deal with early clinical failures. Arthroscopy 28: 225-233.

Dhollander AA, Verdonk PC, Lambrecht S, Verdonk R, Elewaut D, Verbruggen G, Almqvist KF (2012b) Midterm results of the treatment of cartilage defects in the knee using alginate beads containing human mature allogenic chondrocytes. Am J Sports Med 40: 75-82.

Diekman BO, Christoforou N, Willard VP, Sun H, Sanchez-Adams J, Leong KW, Guilak F (2012) Cartilage tissue engineering using differentiated and purified induced pluripotent stem cells. Proc Natl Acad Sci USA 109: 19172 19177.

Dowthwaite GP, Bishop JC, Redman SN, Khan IM, Rooney P, Evans DJ, Haughton L, Bayram Z, Boyer S, Thomson B, Wolfe MS, Archer CW (2004) The surface of articular cartilage contains a progenitor cell population. J Cell Sci 117: 889-897.

Drukker M, Katz G, Urbach A, Schuldiner M, Markel G, Itskovitz-Eldor J, Reubinoff B, Mandelboim O, Benvenisty N (2002) Characterization of the expression of MHC proteins in human embryonic stem cells. Proc Natl Acad Sci USA 99: 9864-9869.

Ehrbar M, Rizzi SC, Schoenmakers RG, San Miguel B, Hubbell JA, Weber FE, Lutolf MP (2007) Biomolecular hydrogels formed and degraded via site-specific enzymatic reactions. Biomacromolecules 8: 3000-3007.

Elisseeff J, Anseth K, Sims D, McIntosh W, Randolph M, Langer R (1999) Transdermal photopolymerization for minimally invasive implantation. Proc Natl Acad Sci USA 96: 3104-3107.

Elisseeff J, McIntosh W, Anseth K, Riley S, Ragan P, Langer R (2000) Photoencapsulation of chondrocytes in poly(ethylene oxide)-based semi-interpenetrating networks. J Biomed Mater Res 51: 164-171.

Erickson GR, Gimble JM, Franklin DM, Rice HE, Awad H, Guilak F (2002) Chondrogenic potential of adipose tissue-derived stromal cells in vitro and in vivo. Biochem Biophys Res Commun 290: 763-769.

Erickson IE, Huang AH, Chung C, Li RT, Burdick JA, Mauck RL (2009) Differential maturation and structurefunction relationships in mesenchymal stem cell- and chondrocyte-seeded hydrogels. Tissue Eng Part A 15: 1041-1052.

Erickson IE, Kestle SR, Zellars KH, Farrell MJ, Kim M, Burdick JA, Mauck RL (2012) High mesenchymal stem cell seeding densities in hyaluronic acid hydrogels produce engineered cartilage with native tissue properties. Acta Biomater 8: 3027-3034.

Estes BT, Diekman BO, Gimble JM, Guilak F (2010) Isolation of adipose-derived stem cells and their induction to a chondrogenic phenotype. Nat Protoc 5: 1294-1311.

Evans CH (2011) Barriers to the clinical translation of orthopedic tissue engineering. Tissue Eng Part B Rev 17: 437-441.

Evans CH, Robbins PD (1995) Progress toward the treatment of arthritis by gene therapy. Ann Med 27: 543546.
Evans CH, Ghivizzani SC, Herndon JH, Robbins PD (2005a) Gene therapy for the treatment of musculoskeletal diseases. J Am Acad Orthop Surg 13: 230-242.

Evans CH, Robbins PD, Ghivizzani SC, Wasko MC, Tomaino MM, Kang R, Muzzonigro TA, Vogt M, Elder EM, Whiteside TL, Watkins SC, Herndon JH (2005b) Gene transfer to human joints: progress toward a gene therapy of arthritis. Proc Natl Acad Sci USA 102: 8698-8703.

Evans CH, Ghivizzani SC, Robbins PD (2011) Getting arthritis gene therapy into the clinic. Nat Rev Rheumatol 7: 244-249.

Facchini A, Lisignoli G, Cristino S, Roseti L, De Franceschi L, Marconi E, Grigolo B (2006) Human chondrocytes and mesenchymal stem cells grown onto engineered scaffold. Biorheology 43: 471-480.

Farr J, Cole B, Dhawan A, Kercher J, Sherman S (2011) Clinical cartilage restoration: evolution and overview. Clin Orthop Relat Res 469: 2696-2705.

Flanigan DC, Harris JD, Trinh TQ, Siston RA, Brophy RH (2010) Prevalence of chondral defects in athletes' knees: a systematic review. Med Sci Sports Exerc 42: 1795-1801.

Freed LE, Marquis JC, Nohria A, Emmanual J, Mikos AG, Langer R (1993) Neocartilage formation in vitro and in vivo using cells cultured on synthetic biodegradable polymers. J Biomed Mater Res 27: 11-23.

Freed LE, Grande DA, Lingbin Z, Emmanual J, Marquis JC, Langer R (1994) Joint resurfacing using allograft chondrocytes and synthetic biodegradable polymer scaffolds. J Biomed Mater Res 28: 891-899.

Freed LE, Hollander AP, Martin I, Barry JR, Langer R, Vunjak-Novakovic G (1998) Chondrogenesis in a cellpolymer-bioreactor system. Exp Cell Res 240: 58-65.

Freed LE, Engelmayr GC, Jr., Borenstein JT, Moutos FT, Guilak F (2009) Advanced material strategies for tissue engineering scaffolds. Adv Mater 21: 3410-3418.

Frenkel SR, Toolan B, Menche D, Pitman MI, Pachence JM (1997) Chondrocyte transplantation using a collagen bilayer matrix for cartilage repair. J Bone Joint Surg Br 79: 831-836.

Gelse K, Jiang QJ, Aigner T, Ritter T, Wagner K, Poschl E, von der MK, Schneider H (2001) Fibroblast-mediated delivery of growth factor complementary DNA into mouse joints induces chondrogenesis but avoids the disadvantages of direct viral gene transfer. Arthritis Rheum 44: 19431953.

Gelse K, Muhle C, Franke O, Park J, Jehle M, Durst K, Goken M, Hennig F, von der Mark K, Schneider H (2008) Cell-based resurfacing of large cartilage defects: long-term evaluation of grafts from autologous transgene-activated periosteal cells in a porcine model of osteoarthritis. Arthritis Rheum 58: 475-488.

Goa KL, Benfield P (1994) Hyaluronic acid - A review of its pharmacology and use as a surgical aid in ophthalmology, and its therapeutic potential in joint disease and wound healing. Drugs 47: 536-566.

Gomoll AH, Madry H, Knutsen G, van DN, Seil R, Brittberg M, Kon E (2010) The subchondral bone in articular cartilage repair: current problems in the surgical management. Knee Surg Sports Traumatol Arthrosc 18: 434-447. 
Gomoll AH, Filardo G, de Girolamo L, EsprequeiraMendes J, Marcacci M, Rodkey WG, Steadman RJ, Zaffagnini S, Kon E (2012) Surgical treatment for early osteoarthritis. Part I: cartilage repair procedures. Knee Surg Sports Traumatol Arthrosc 20: 450-466.

Goodrich LR, Hidaka C, Robbins PD, Evans CH, Nixon AJ (2007) Genetic modification of chondrocytes with insulin-like growth factor-1 enhances cartilage healing in an equine model. J Bone Joint Surg Br 89: 672-685.

Grad S, Eglin D, Alini M, Stoddart MJ (2011) Physical stimulation of chondrogenic cells in vitro: a review. Clin Orthop Relat Res 469: 2764-2772.

Grigolo B, Roseti L, Fiorini M, Fini M, Giavaresi G, Aldini NN, Giardino R, Facchini A (2001) Transplantation of chondrocytes seeded on a hyaluronan derivative (Hyaff (R)-11) into cartilage defects in rabbits. Biomaterials 22: 2417-2424.

Guilak F, Butler DL, Goldstein SA (2001) Functional tissue engineering: the role of biomechanics in articular cartilage repair. Clin Orthop Relat Res 391: S295-S305.

Guilak F, Estes BT, Diekman BO, Moutos FT, Gimble JM (2010) Multipotent adult stem cells from adipose tissue for musculoskeletal tissue engineering. Clin Orthop Relat Res 468: 2530-2540.

Gysin R, Wergedal JE, Sheng MH, Kasukawa Y, Miyakoshi N, Chen ST, Peng H, Lau KH, Mohan S, Baylink DJ (2002) Ex vivo gene therapy with stromal cells transduced with a retroviral vector containing the BMP4 gene completely heals critical size calvarial defect in rats. Gene Ther 9: 991-999.

Haddo O, Mahroof S, Higgs D, David L, Pringle J, Bayliss M, Cannon SR, Briggs TW (2004) The use of chondrogide membrane in autologous chondrocyte implantation. Knee 11: 51-55.

Haleem-Smith H, Derfoul A, Okafor C, Tuli R, Olsen D, Hall DJ, Tuan RS (2005) Optimization of highefficiency transfection of adult human mesenchymal stem cells in vitro. Mol Biotechnol 30: 9-20.

Harichandan A, Buhring HJ (2011) Prospective isolation of human MSC. Best Pract Res Clin Haematol 24: 25-36.

Hartgerink JD, Beniash E, Stupp SI (2001) Selfassembly and mineralization of peptide-amphiphile nanofibers. Science 294: 1684-1688.

Hauselmann HJ, Aydelotte MB, Schumacher BL, Kuettner KE, Gitelis SH, Thonar EJ (1992) Synthesis and turnover of proteoglycans by human and bovine adult articular chondrocytes cultured in alginate beads. Matrix 12: 116-129.

Heiligenstein S, Cucchiarini M, Laschke MW, Bohle RM, Kohn D, Menger MD, Madry H (2011) Evaluation of nonbiomedical and biomedical grade alginates for the transplantation of genetically modified articular chondrocytes to cartilage defects in a large animal model in vivo. J Gene Med 13: 230-242.

Hidaka C, Goodrich LR, Chen CT, Warren RF, Crystal RG, Nixon AJ (2003) Acceleration of cartilage repair by genetically modified chondrocytes over expressing bone morphogenetic protein-7. J Orthop Res 21: 573-583.
Hoben GM, Willard VP, Athanasiou KA (2009) Fibrochondrogenesis of hESCs: growth factor combinations and cocultures. Stem Cells Dev 18: 283-292.

$\mathrm{Hu}$ JC, Athanasiou KA (2006) A self-assembling process in articular cartilage tissue engineering. Tissue Eng 12: 969-979.

Huang AH, Motlekar NA, Stein A, Diamond SL, Shore EM, Mauck RL (2008) High-throughput screening for modulators of mesenchymal stem cell chondrogenesis. Ann Biomed Eng 36: 1909-1921.

Huang AH, Farrell MJ, Mauck RL (2010a) Mechanics and mechanobiology of mesenchymal stem cell-based engineered cartilage. J Biomech 43: 128-136.

Huang AH, Stein A, Mauck RL (2010b) Evaluation of the complex transcriptional topography of mesenchymal stem cell chondrogenesis for cartilage tissue engineering. Tissue Eng Part A 16: 2699-2708.

Hung CT, Lima EG, Mauck RL, Takai E, LeRoux MA, Lu HH, Stark RG, Guo XE, Ateshian GA (2003) Anatomically shaped osteochondral constructs for articular cartilage repair. J Biomech 36: 1853-1864.

Hunziker EB (1999) Biologic repair of articular cartilage. Defect models in experimental animals and matrix requirements. Clin Orthop Relat Res 367: S135-S146.

Hwang NS, Varghese S, Lee HJ, Zhang Z, Ye Z, Bae J, Cheng L, Elisseeff J (2008) In vivo commitment and functional tissue regeneration using human embryonic stem cell-derived mesenchymal cells. Proc Natl Acad Sci USA 105: 20641-20646.

Hwang NS, Varghese S, Li H, Elisseeff J (2011) Regulation of osteogenic and chondrogenic differentiation of mesenchymal stem cells in PEG-ECM hydrogels. Cell Tissue Res 344: 499-509.

Itay S, Abramovici A, Nevo Z (1987) Use of cultured embryonal chick epiphyseal chondrocytes as grafts for defects in chick articular cartilage. Clin Orthop Relat Res 220: 284-303.

Ivkovic A, Pascher A, Hudetz D, Maticic D, Jelic M, Dickinson S, Loparic M, Haspl M, Windhager R, Pecina M (2010) Articular cartilage repair by genetically modified bone marrow aspirate in sheep. Gene Ther 17: 779-789.

Ivkovic A, Marijanovic I, Hudetz D, Porter RM, Pecina M, Evans CH (2011) Regenerative medicine and tissue engineering in orthopaedic surgery. Front Biosci (Elite Ed) 3: 923-944.

Johnstone B, Hering TM, Caplan AI, Goldberg VM, Yoo JU (1998) In vitro chondrogenesis of bone marrowderived mesenchymal progenitor cells. Exp Cell Res 238: 265-272.

Kaul G, Cucchiarini M, Arntzen D, Zurakowski D, Menger MD, Kohn D, Trippel SB, Madry H (2006) Local stimulation of articular cartilage repair by transplantation of encapsulated chondrocytes overexpressing human fibroblast growth factor 2 (FGF-2) in vivo. J Gene Med 8: 100-111.

Khademhosseini A, Langer R, Borenstein J, Vacanti JP (2006) Microscale technologies for tissue engineering and biology. Proc Natl Acad Sci USA 103: 2480-2487. 
Khan IM, Bishop JC, Gilbert S, Archer CW (2009) Clonal chondroprogenitors maintain telomerase activity and Sox9 expression during extended monolayer culture and retain chondrogenic potential. Osteoarthritis Cartilage 17: $518-528$.

Kim IL, Mauck RL, Burdick JA (2011a) Hydrogel design for cartilage tissue engineering: A case study with hyaluronic acid. Biomaterials 32: 8771-8782.

Kim M, Kraft JJ, Volk AC, Pugarelli J, Pleshko N, Dodge GR (2011b) Characterization of a cartilage-like engineered biomass using a self-aggregating suspension culture model: molecular composition using FT-IRIS. J Orthop Res 29: 1881-1887.

Kisiday J, Jin M, Kurz B, Hung H, Semino C, Zhang S, Grodzinsky AJ (2002) Self-assembling peptide hydrogel fosters chondrocyte extracellular matrix production and cell division: Implications for cartilage tissue repair. Proc Natl Acad Sci USA 99: 9996-10001.

Klein TJ, Rizzi SC, Reichert JC, Georgi N, Malda J, Schuurman W, Crawford RW, Hutmacher DW (2009) Strategies for zonal cartilage repair using hydrogels. Macromolecular Bioscience 9: 1049-1058.

Knutsen G, Drogset JO, Engebretsen L, Grontvedt T, Isaksen V, Ludvigsen TC, Roberts S, Solheim E, Strand T, Johansen O (2007) A randomized trial comparing autologous chondrocyte implantation with microfracture. Findings at five years. J Bone Joint Surg Am 89: 21052112.

Koay EJ, Athanasiou KA (2009) Development of serum-free, chemically defined conditions for human embryonic stem cell-derived fibrochondrogenesis. Tissue Eng Part A 15: 2249-2257.

Kopesky PW, Vanderploeg EJ, Sandy JS, Kurz B, Grodzinsky AJ (2010) Self-assembling peptide hydrogels modulate in vitro chondrogenesis of bovine bone marrow stromal cells. Tissue Eng Part A 16: 465-477.

Kraft JJ, Jeong C, Novotny JE, Seacrist T, Chan G, Domzalski M, Turka CM, Richardson DW, Dodge GR (2011) Effects of hydrostatic loading on a self-aggregating, suspension culture-derived cartilage tissue analog. Cartilage 2: 254-264.

Kupcsik L, Stoddart MJ, Li Z, Benneker LM, Alini M (2009) Improving chondrogenesis: potential and limitations of SOX9 gene transfer and mechanical stimulation for cartilage tissue engineering. Tissue Eng Part A 16: 1845-1855.

Kuroda R, Ishida K, Matsumoto T, Akisue T, Fujioka H, Mizuno K, Ohgushi H, Wakitani S, Kurosaka M (2007) Treatment of a full-thickness articular cartilage defect in the femoral condyle of an athlete with autologous bonemarrow stromal cells. Osteoarthritis Cartilage 15: 226-231.

Langer R, Vacanti JP (1993) Tissue engineering. Science 260: 920-926.

Latt LD, Glisson RR, Montijo HE, Usuelli FG, Easley ME (2011) Effect of graft height mismatch on contact pressures with osteochondral grafting of the talus. Am J Sports Med 39: 2662-2669.

Laverty S, Girard CA, Williams JM, Hunziker EB, Pritzker KP (2010) The OARSI histopathology initiative - recommendations for histological assessments of osteoarthritis in the rabbit. Osteoarthritis Cartilage 18 Suppl 3: S53-S65.

Lee CR, Grodzinsky AJ, Hsu HP, Martin SD, Spector M (2000) Effects of harvest and selected cartilage repair procedures on the physical and biochemical properties of articular cartilage in the canine knee. J Orthop Res 18: 790-799.

Lee CH, Cook JL, Mendelson A, Moioli EK, Yao H, Mao JJ (2010) Regeneration of the articular surface of the rabbit synovial joint by cell homing: a proof of concept study. Lancet 376: 440-448.

Lefebvre V, Zhou G, Mukhopadhyay K, Smith CN, Zhang Z, Eberspaecher H, Zhou X, Sinha S, Maity SN, de CB (1996) An 18-base-pair sequence in the mouse proalpha1(II) collagen gene is sufficient for expression in cartilage and binds nuclear proteins that are selectively expressed in chondrocytes. Mol Cell Biol 16: 4512-4523.

Li WJ, Danielson KG, Alexander PG, Tuan RS (2003) Biological response of chondrocytes cultured in threedimensional nanofibrous poly(epsilon-caprolactone) scaffolds. J Biomed Mater Res A 67: 1105-1114.

Li WJ, Jiang YJ, Tuan RS (2006) Chondrocyte phenotype in engineered fibrous matrix is regulated by fiber size. Tissue Eng 12: 1775-1785.

Li WJ, Mauck RL, Cooper JA, Yuan X, Tuan RS (2007) Engineering controllable anisotropy in electrospun biodegradable nanofibrous scaffolds for musculoskeletal tissue engineering. J Biomech 40: 1686-1693.

Li WJ, Chiang H, Kuo TF, Lee HS, Jiang CC, Tuan RS (2009) Evaluation of articular cartilage repair using biodegradable nanofibrous scaffolds in a swine model: a pilot study. J Tissue Eng Regen Med 3: 1-10.

Liao E, Yaszemski M, Krebsbach P, Hollister S (2007) Tissue-engineered cartilage constructs using composite hyaluronic acid/collagen I hydrogels and designed poly(propylene fumarate) scaffolds. Tissue Engineering 13: $537-550$.

Lima EG, Bian L, Ng KW, Mauck RL, Byers BA, Tuan RS, Ateshian GA, Hung CT (2007) The beneficial effect of delayed compressive loading on tissue-engineered cartilage constructs cultured with TGF-beta3. Osteoarthritis Cartilage 15: 1025-1033.

Liu J, Song H, Zhang L, Xu H, Zhao X (2010) Selfassembly-peptide hydrogels as tissue-engineering scaffolds for three-dimensional culture of chondrocytes in vitro. Macromol Bioscie 10: 1164-1170.

Lories RJ, Luyten FP (2011) The bone-cartilage unit in osteoarthritis. Nat Rev Rheumatol 7: 43-49.

Lutolf MP, Lauer-Fields JL, Schmoekel HG, Metters AT, Weber FE, Fields GB, Hubbell JA (2003) Synthetic matrix metalloproteinase-sensitive hydrogels for the conduction of tissue regeneration: engineering cellinvasion characteristics. Proc Natl Acad Sci USA 100: 5413-5418.

Lutolf MP, Hubbell JA (2005) Synthetic biomaterials as instructive extracellular microenvironments for morphogenesis in tissue engineering. Nat Biotechnol 23: 47-55.

MacEwan SR, Chilkoti A (2010) Elastin-like polypeptides: biomedical applications of tunable biopolymers. Biopolymers 94: 60-77. 
Madry H (2010) The subchondral bone: a new frontier in articular cartilage repair. Knee Surg Sports Traumatol Arthrosc 18: 417-418.

Madry H, Cucchiarini M (2011) Clinical potential and challenges of using genetically modified cells for articular cartilage repair. Croat Med J 52: 245-261.

Madry H, Padera R, Seidel J, Langer R, Freed LE, Trippel SB, Vunjak-Novakovic G (2002) Gene transfer of a human insulin-like growth factor I cDNA enhances tissue engineering of cartilage. Hum Gene Ther 13: 1621-1630.

Madry H, Kaul G, Cucchiarini M, Stein U, Zurakowski D, Remberger K, Menger MD, Kohn D, Trippel SB (2005) Enhanced repair of articular cartilage defects in vivo by transplanted chondrocytes overexpressing insulin-like growth factor I (IGF-I). Gene Ther 12: 1171-1179.

Madry H, Orth P, Kaul G, Zurakowski D, Menger MD, Kohn D, Cucchiarini M (2010a) Acceleration of articular cartilage repair by combined gene transfer of human insulin-like growth factor I and fibroblast growth factor-2 in vivo. Arch Orthop Trauma Surg 130: 1311-1322.

Madry H, van Dijk CN, Mueller-Gerbl M (2010b) The basic science of the subchondral bone. Knee Surg Sports Traumatol Arthrosc 18: 419-433.

Madry H, Orth P, Cucchiarini M (2011) Gene therapy for cartilage repair. Cartilage 2: 201-225.

Majumdar MK, Wang E, Morris EA (2001) BMP-2 and BMP-9 promotes chondrogenic differentiation of human multipotential mesenchymal cells and overcomes the inhibitory effect of IL-1. J Cell Physiol 189: 275-284.

Mankin HJ (1982) The response of articular cartilage to mechanical injury. J Bone Joint Surg Am 64: 460-466.

Masuda K, Sah RL, Hejna MJ, Thonar EJ (2003) A novel two-step method for the formation of tissueengineered cartilage by mature bovine chondrocytes: the alginate-recovered-chondrocyte (ARC) method. J Orthop Res 21: 139-148.

Matricali GA, Dereymaeker GP, Luyten FP (2010) Donor site morbidity after articular cartilage repair procedures: a review. Acta Orthop Belg 76: 669-674.

Mauck RL, Baker BM, Nerurkar NL, Burdick JA, Li WJ, Tuan RS, Elliott DM (2009) Engineering on the straight and narrow: the mechanics of nanofibrous assemblies for fiber-reinforced tissue regeneration. Tissue Eng Part B Rev 15: 171-193.

McCarthy HE, Bara JJ, Brakspear K, Singhrao SK, Archer CW (2012) The comparison of equine articular cartilage progenitor cells and bone marrow-derived stromal cells as potential cell sources for cartilage repair in the horse. Vet J 192: 345-351.

McCormick F, Yanke A, Provencher MT, Cole BJ (2008) Minced articular cartilage--basic science, surgical technique, and clinical application. Sports Med Arthrosc 16: $217-220$.

McCullen SD, Autefage H, Callanan A, Gentleman E, Stevens MM (2012) Anisotropic fibrous scaffolds for articular cartilage regeneration. Tissue Eng Part A 18: 2073-2083.

Mortisen D, Peroglio M, Alini M, Eglin D (2010) Tailoring thermoreversible hyaluronan hydrogels by "Click" chemistry and RAFT polymerization for cell and drug therapy. Biomacromolecules 11: 1261-1272.
Moskalewski S, Hyc A, Osiecka-Iwan A (2002) Immune response by host after allogeneic chondrocyte transplant to the cartilage. Microsc Res Tech 58: 3-13.

Moutos FT, Freed LE, Guilak F (2007) A biomimetic three-dimensional woven composite scaffold for functional tissue engineering of cartilage. Nat Mater 6: 162-167.

Moutos FT, Guilak F (2010) Functional properties of cell-seeded three-dimensionally woven poly(epsiloncaprolactone) scaffolds for cartilage tissue engineering. Tissue Eng Part A 16: 1291-1301.

Mow VC, Ratcliffe A, Poole AR (1992) Cartilage and diarthrodial joints as paradigms for hierarchical materials and structures. Biomaterials 13: 67-97.

Mwale F, Stachura D, Roughley P, Antoniou J (2006) Limitations of using aggrecan and type $\mathrm{X}$ collagen as markers of chondrogenesis in mesenchymal stem cell differentiation. J Orthop Res 24: 1791-1798.

Nakahara H, Goldberg VM, Caplan AI (1991) Culture-expanded human periosteal-derived cells exhibit osteochondral potential in vivo. J Orthop Res 9: 465-476.

Nehrer S, Breinan HA, Ramappa A, Hsu HP, Minas T, Shortkroff S, Sledge CB, Yannas IV, Spector M (1998) Chondrocyte-seeded collagen matrices implanted in a chondral defect in a canine model. Biomaterials 19: 23132328.

Nejadnik H, Hui JH, Feng Choong EP, Tai BC, Lee EH (2010) Autologous bone marrow-derived mesenchymal stem cells versus autologous chondrocyte implantation: an observational cohort study. Am J Sports Med 38: 11101116.

Neumann AJ, Schroeder J, Alini M, Archer CW, Stoddart MJ (2013) Enhanced adenovirus transduction of hMSCs using 3D hydrogel cell carriers. Mol Biotechnol 53: $207-216$.

Nguyen LH, Kudva AK, Saxena NS, Roy K (2011) Engineering articular cartilage with spatially-varying matrix composition and mechanical properties from a single stem cell population using a multi-layered hydrogel. Biomaterials 32: 6946-6952.

Niemeyer P, Andereya S, Angele P, Ateschrang A, Aurich M, Baumann M, Behrens P, Bosch U, Erggelet C, Fickert S, Fritz J, Gebhard H, Gelse K, Gunther D, Hoburg A, Kasten P, Kolombe T, Madry H, Marlovits S, Meenen NM, Muller PE, Noth U, Petersen JP, Pietschmann M, Richter W, Rolauffs B, Rhunau K, Schewe B, Steinert A, Steinwachs MR, Welsch GH, Zinser W, Albrecht D (2013) [Autologous chondrocyte implantation (ACI) for cartilage defects of the knee: a guideline by the working group "Tissue Regeneration" of the German Society of Orthopaedic Surgery and Traumatology (DGOU)]. Z Orthop Unfall 151: 38-47.

Novotny JE, Turka CM, Jeong C, Wheaton AJ, Li C, Presedo A, Richardson DW, Reddy R, Dodge GR (2006) Biomechanical and magnetic resonance characteristics of a cartilage-like equivalent generated in a suspension culture. Tissue Eng 12: 2755-2764.

O’Leary LER, Fallas JA, Bakota EL, Kang MK, Hartgerink JD (2011) Multi-hierarchical self-assembly of a collagen mimetic peptide from triple helix to nanofibre and hydrogel. Nat Chem 3: 821-828. 
Ofek G, Revell CM, Hu JC, Allison DD, Grande-Allen KJ, Athanasiou KA (2008) Matrix development in selfassembly of articular cartilage. PLoS ONE 3: e2795.

Orth P, Zurakowski D, Wincheringer D, Madry H (2012) Reliability, reproducibility, and validation of five major histological scoring systems for experimental articular cartilage repair in the rabbit model. Tissue Eng Part C Methods 18: 329-339.

Ousema PH, Moutos FT, Estes BT, Caplan AI, Lennon DP, Guilak F, Weinberg JB (2012) The inhibition by interleukin 1 of MSC chondrogenesis and the development of biomechanical properties in biomimetic 3D woven PCL scaffolds. Biomaterials 33: 8967-8974.

Ozbas B, Rajagopal K, Haines-Butterick L, Schneider JP, Pochan DJ (2007) Reversible stiffening transition in beta-hairpin hydrogels induced by ion complexation. J Phys Chem B 111: 13901-13908.

Park S, Hung CT, Ateshian GA (2004) Mechanical response of bovine articular cartilage under dynamic unconfined compression loading at physiological stress levels. Osteoarthritis Cartilage 12: 65-73.

Park J, Gelse K, Frank S, von der Mark K, Aigner T, Schneider H (2006) Transgene-activated mesenchymal cells for articular cartilage repair: a comparison of primary bone marrow-, perichondrium/periosteum- and fat-derived cells. J Gene Med 8: 112-125.

Pelttari K, Winter A, Steck E, Goetzke K, Hennig T, Ochs BG, Aigner T, Richter W (2006) Premature induction of hypertrophy during in vitro chondrogenesis of human mesenchymal stem cells correlates with calcification and vascular invasion after ectopic transplantation in SCID mice. Arthritis Rheum 54: 3254-3266.

Pena E, Calvo B, Martinez MA, Doblare M (2007) Effect of the size and location of osteochondral defects in degenerative arthritis. A finite element simulation. Comput Biol Med 37: 376-387.

Pittenger MF, Mackay AM, Beck SC, Jaiswal RK, Douglas R, Mosca JD, Moorman MA, Simonetti DW, Craig S, Marshak DR (1999) Multilineage potential of adult human mesenchymal stem cells. Science 284: 143-147.

Pochan DJ, Schneider JP, Kretsinger J, Ozbas B, Rajagopal K, Haines L (2003) Thermally reversible hydrogels via intramolecular folding and consequent selfassembly of a de novo designed peptide. J Am Chem Soc 125: $11802-11803$.

Poole AR, Kojima T, Yasuda T, Mwale F, Kobayashi M, Laverty S (2001) Composition and structure of articular cartilage - A template for tissue repair. Clin Orthop Relat Res 391: S26-S33.

Quinatana L, Fernandez Muinos T, Genove E, Del Mar Olmos M, Borros S, Semino CE (2009) Early tissue patterning recreated by mouse embryonic fibroblasts in a three-dimensional environment. Tissue Eng Part A 15: 45-54.

Rahfoth B, Weisser J, Sternkopf F, Aigner T, von der MK, Brauer R (1998) Transplantation of allograft chondrocytes embedded in agarose gel into cartilage defects of rabbits. Osteoarthritis Cartilage 6: 50-65.

Rampichova M, Filova E, Varga F, Lytvynets A, Prosecka E, Kolacna L, Motlik J, Necas A, Vajner L, Uhlik J, Amler E (2010) Fibrin/hyaluronic acid composite hydrogels as appropriate scaffolds for in vivo artificial cartilage implantation. ASAIO J 56: 563-568.

Robbins PD, Evans CH, Chernajovsky Y (2003) Gene therapy for arthritis. Gene Ther 10: 902-911.

Safran MR, Kim H, Zaffagnini S (2008) The use of scaffolds in the management of articular cartilage injury. J Am Acad Orthop Surg 16: 306-311.

Salzmann GM, Nuernberger B, Schmitz P, Anton M, Stoddart MJ, Grad S, Milz S, Tischer T, Vogt S, Gansbacher B, Imhoff AB, Alini M (2009) Physicobiochemical synergism through gene therapy and functional tissue engineering for in vitro chondrogenesis. Tissue Eng Part A 15: 2513-2524.

Schneider JP, Pochan DJ, Ozbas B, Rajagopal K, Pakstis L, Kretsinger J (2002) Responsive hydrogels from the intramolecular folding and self-assembly of a designed peptide. J Am Chem Soc 124: 15030-15037.

Schneider T, Kohl B, Sauter T, Kratz K, Lendlein A, Ertel W, Schulze-Tanzil G (2012) Influence of fiber orientation in electrospun polymer scaffolds on viability, adhesion and differentiation of articular chondrocytes. Clin Hemorheol Microcirc 52: 325-336.

Shah RN, Shah NA, Lim MMDR, Hsieh C, Nuber G, Stupp SI (2010) Supramolecular design of self-assembling nanofibers for cartilage regeneration. Proc Natl Acad Sci USA 107: 3293-3298.

Shields KJ, Beckman MJ, Bowlin GL, Wayne JS (2004) Mechanical properties and cellular proliferation of electrospun collagen type II. Tissue Eng 10: 1510-1517.

Sims CD, Butler PE, Cao YL, Casanova R, Randolph MA, Black A, Vacanti CA, Yaremchuk MJ (1998) Tissue engineered neocartilage using plasma derived polymer substrates and chondrocytes. Plast Reconstr Surg 101: 1580-1585.

Slaughter BV, Khurshid SS, Fisher OZ, Khademhosseini A, Peppas NA (2009) Hydrogels in regenerative medicine. Advanced Materials 21: 3307-3329.

Smeds KA, Pfister-Serres A, Miki D, Dastgheib K, Inoue M, Hatchell DL, Grinstaff MW (2001) Photocrosslinkable polysaccharides for in situ hydrogel formation. J Biomed Mater Res 54: 115-121.

Stoddart MJ, Ettinger L, Hauselmann HJ (2006) Enhanced matrix synthesis in de novo, scaffold-free cartilage-like tissue subjected to compression and shear. Biotechnol Bioeng 95: 1043-1051.

Stoop R (2008) Smart biomaterials for tissue engineering of cartilage. Injury 39: S77-S87.

Sun N, Longaker MT, Wu JC (2010) Human iPS cellbased therapy: considerations before clinical applications. Cell Cycle 9: 880-885.

Tay AG, Farhadi J, Suetterlin R, Pierer G, Heberer M, Martin I (2004) Cell yield, proliferation, and postexpansion differentiation capacity of human ear, nasal, and rib chondrocytes. Tissue Eng 10: 762-770.

Thorvaldsson A, Stenhamre H, Gatenholm P, Walkenstrom P (2008) Electrospinning of highly porous scaffolds for cartilage regeneration. Biomacromolecules 9: 1044-1049.

Turgeman G, Pittman DD, Muller R, Kurkalli BG, Zhou S, Pelled G, Peyser A, Zilberman Y, Moutsatsos IK, Gazit D (2001) Engineered human mesenchymal stem cells: a 
novel platform for skeletal cell mediated gene therapy. J Gene Med 3: 240-251.

Vacanti CA, Langer R, Schloo B, Vacanti JP (1991) Synthetic polymers seeded with chondrocytes provide a template for new cartilage formation. Plast Reconstr Surg 88: $753-759$.

Vanlauwe J, Saris DB, Victor J, Almqvist KF, Bellemans J, Luyten FP (2011) Five-year outcome of characterized chondrocyte implantation versus microfracture for symptomatic cartilage defects of the knee: early treatment matters. Am J Sports Med 39: 2566-2574.

Vogt S, Wexel G, Tischer T, Schillinger U, Ueblacker P, Wagner B, Hensler D, Wilisch J, Geis C, Wubbenhorst D, Aigner J, Gerg M, Kruger A, Salzmann GM, Martinek V, Anton M, Plank C, Imhoff AB, Gansbacher B (2009) The influence of the stable expression of BMP2 in fibrin clots on the remodelling and repair of osteochondral defects. Biomaterials 30: 2385-2392.

Wehling N, Palmer GD, Pilapil C, Liu F, Wells JW, Muller PE, Evans CH, Porter RM (2009) Interleukin-1beta and tumor necrosis factor alpha inhibit chondrogenesis by human mesenchymal stem cells through NF-kappaBdependent pathways. Arthritis Rheum 60: 801-812.

Wei Y, Zeng W, Wan R, Wang J, Zhou Q, Qiu S, Singh SR (2012) Chondrogenic differentiation of induced pluripotent stem cells from osteoarthritic chondrocytes in alginate matrix. Eur Cell Mater 23: 1-12.

Whitney MJ, Lee A, Ylostalo J, Zeitouni S, Tucker A, Gregory CA (2009) Leukemia inhibitory factor secretion is a predictor and indicator of early progenitor status in adult bone marrow stromal cells. Tissue Eng Part A 15: 33-44.

Wickham MQ, Erickson GR, Gimble JM, Vail TP, Guilak F (2003) Multipotent stromal cells derived from the infrapatellar fat pad of the knee. Clin Orthop Relat Res 412: 196-212.

Williams R, Khan IM, Richardson K, Nelson L, McCarthy HE, Analbelsi T, Singhrao SK, Dowthwaite GP, Jones RE, Baird DM, Lewis H, Roberts S, Shaw HM, Dudhia J, Fairclough J, Briggs T, Archer CW (2010) Identification and clonal characterisation of a progenitor cell sub-population in normal human articular cartilage. PLoS ONE 5: e13246.

Woodfield TB, Guggenheim M, von Rechenberg B, Riesle J, van Blitterswijk CA, Wedler V (2009) Rapid prototyping of anatomically shaped, tissue-engineered implants for restoring congruent articulating surfaces in small joints. Cell Prolif 42: 485-497.

Wu EC, Zhang SG, Hauser CAE (2012) Selfassembling peptides as cell-interactive scaffolds. Adv Func Mater 22: 456-468.

Xie WF, Zhang X, Sakano S, Lefebvre V, Sandell LJ (1999) Trans-activation of the mouse cartilage-derived retinoic acid-sensitive protein gene by Sox9. J Bone Miner Res 14: 757-763.

Zhang SG (2003) Fabrication of novel biomaterials through molecular self-assembly. Nat Biotechnol 21: 11711178 .

Zhao X, Zhang S (2007) Designer self-assembling peptide materials. Macromol Biosci 7: 13-22.

Zhou G, Lefebvre V, Zhang Z, Eberspaecher H, de CB (1998) Three high mobility group-like sequences within a 48-base pair enhancer of the Col2al gene are required for cartilage-specific expression in vivo. J Biol Chem 273: 14989-14997.

Zhu J (2010) Bioactive modification of poly(ethylene glycol) hydrogels for tissue engineering. Biomaterials 31: 4639-4656.

Zuk PA, Zhu M, Mizuno H, Huang J, Futrell JW, Katz AJ, Benhaim P, Lorenz HP, Hedrick MH (2001) Multilineage cells from human adipose tissue: implications for cell-based therapies. Tissue Eng 7: 211-228.

\section{Web References}

1. European Medicines Agency recommends first gene therapy for approval. http://www.ema.europa.eu/ema/ index.jsp?curl=pages/news_and_events/news/2012/07/ news detail_001574.jsp\& $\overline{\mathrm{mid}}=\overline{\mathrm{W}} \mathrm{C} 0 \mathrm{~b} 01 \mathrm{ac} 058004 \mathrm{~d} 5 \mathrm{c} 1$ [20-07-2012].

2. Symmons D, Mathers C, Pfleger B. Global burden of osteoarthritis in the year 2000. World Health Organisation, Geneva.

http://www.who.int/healthinfo/statistics/bod osteoarthritis.pdf [15-08-2006].

\section{Discussion with Reviewers}

Reviewer II: In the section on clinical translation, you mention the key challenge of getting individual investigators to work as a consortium to expand consensus and accelerate translation of cartilage tissue engineering strategies. However, this noble goal can conflict with the current pressures (and incentives) within academic research, where novelty of investigation is valued and bibliometrics such as the $\mathrm{H}$-index are being used increasingly to evaluate scientific productivity. Consequently, many investigators may not reach a point of professional discretion to prioritise cost- and time-intensive translational studies until much later in their career. How might the greater community, possibly through its professional societies, better address this underlying obstacle to consortium research?

Authors: This is an excellent and challenging question. The rise in popularity of metrics that purport to measure the 'value' of an individual academic researcher would seem to be out of step with this fact, that the days of an individual researcher working in isolation are coming to an end as projects increase in complexity. There needs to be recognition of this fact from all strata of the academic research infrastructure. The metrics are not going away, so use of those appropriate for modern scientific inquiry is crucial. Many metrics fail to account for the timeintensive nature of translational studies. Perhaps this is where professional societies can play a role - advocating for more appropriate values to be used when assessing the collaborations that a young investigator has entered into. An intermediate step might be an adjustment in the value placed on journals that publish translational research. In targeting solutions to defined problems, papers can be rejected from mainstream journals for being too observational. We are already seeing major journals 
producing more specialised versions with translational subjects, elevating those subjects and allowing younger investigators new avenues to higher metrics. At least funding bodies are embracing multi-centre consortium applications to a greater extent, and such a mechanism was employed by AOERB in bringing this group of researchers together, since it is unlikely that one group alone could address and solve the challenge of cartilage repair.

Reviewer II: Can you provide a specific lesson learned from your collective experience in the Acute Cartilage Injury Collaborative Research Program regarding multidisciplinary collaboration in cartilage tissue engineering? Perhaps a success story to inspire the eCM readership?

Authors: When the consortium was set up, the partners were selected from a peer-reviewed pool of individually submitted ideas. Thus, for those selected, the challenge has been to find ways to "make the sum of the consortium greater than the total of its parts'. To this end, we began by discussing each partner's projects in detail to find all the points at which other partners could intersect with it. This openness led to agreement about which cell sources, models, tests and analyses all partners could use, exchanges of materials and techniques, and of course, the discussions of the problem that produced this review.

Reviewer III: How would you address the problem that neo-cartilage will be surrounded by normal cartilage with different mechanical properties? This could lead to accelerated destruction of the repair tissue.

Authors: This is an often-overlooked challenge, as the focus to date has been on producing large amounts of tissue. Mature cartilage replacements do not integrate well with the surrounding tissue, but we do not know what level of maturity an implant should be that would allow integration, while maintaining function and avoiding breakdown. Methods that rapidly induce maturation of neocartilage might be one direction to take (Khan et al., 2011).

\section{Additional Reference}

Khan IM, Evans SL, Young RD, Blain EJ, Quantock AJ, Avery N, Archer CW (2011) Fibroblast growth factor 2 and transforming growth factor betal induce precocious maturation of articular cartilage. Arthritis Rheum 63: 34173427. 